\title{
Devoção e identidades: significados do culto de Santo Elesbão e Santa Efigênia no Rio de Janeiro e nas Minas Gerais no Setecentos
}

\section{Devotion and Identities: meanings os Santo Elesbão and Santa Efigênia cults in Rio de Janeiro and in Minas Gerais during the 1700 s}

\section{Anderson José Machado de Oliveira}

\section{1 - Santos Pretos e Catequese}

O caráter fundamental que a escravidão africana assumiu para o Império colonial português não poderia deixar a Igreja sem refletir sobre a questão. A própria estrutura social, fundada nas diferenças e hierarquias, exigiu um projeto específico de cristianização dos africanos e seus descendentes. Com efeito, a catequese, enquanto um discurso que pretendia produzir uma unidade de procedimentos e crenças, não pôde fazê-lo sem levar em consideração as diferenças sociais e a necessidade de reproduzilas para o bom funcionamento dos padrões do Antigo Regime.

Por outro lado, a própria conjuntura, da segunda metade do século XVII em diante, colocava a urgência em se pensar a questão africana, na medida em que africanos e seus descendentes tornaram-se o maior contingente populacional da América Portuguesa, principalmente quando da explosão do tráfico atlântico nas primeiras décadas do século XVIII ${ }^{1}$. Do lado senhorial, a questão de Palmares exigia uma melhor definição do projeto escravista-cristão ${ }^{2}$. 
Antonio Vieira foi um dos primeiros a refletir sobre a questão. $\mathrm{O}$ Sermão XIV do Rosário, de 1633, trabalhava a idéia da escravidão africana como castigo e dádiva, onde a divindade colocava para os "pretos" a possibilidade de resgate do pecado. Segundo Vieira, os negros deveriam ser gratos pelo fato de terem sido arrancados da África e trazidos ao Brasil. Na condição de escravos estariam numa situação melhor do que aqueles que permaneceram em meio ao gentilismo inerente aos povos africanos. A força para suportar os sofrimentos do cativeiro e ver neles a possibilidade do resgate estaria na devoção ao Rosário de Maria³.

Ao final do seiscentos e início do setecentos, as preocupações com a conversão dos negros intensificaram-se. Algumas obras publicadas no século XVIII atestaram este processo. Destacaram-se os trabalhos dos jesuítas Jorge Benci (Economia Cristã dos Senhores no Governo dos Escravos), André João Antonil (Cultura e Opulência do Brasil) e do padre Manoel Ribeiro da Rocha (Etíope Resgatado: empenhado, sustentado, corrigido, instruído e libertado). A preocupação com o governo dos escravos não estava dissociada da necessidade de cristianizá-los. Para Jorge Benci era imperioso vencer a ignorância, pois o desconhecimento dos africanos da Lei de Deus implicava um fator de desestabilidade social ${ }^{4}$. As Constituiçôes Primeiras do Arcebispado da Bahia, de 1707, também expressaram a preocupação com a conversão dos negros, tanto que traziam um catecismo especial dedicado à catequese dos escravos, era este a Breve Instrução nos Mistérios da Fé, acomodado ao modo de falar dos escravos do Brasil, para serem catequizados por ela.

Ciente do seu papel na manutenção de uma estrutura social excludente, a Igreja multiplicou as suas ações na tarefa de inserção dos chamados "homens de cor" no interior da Cristandade. A multiplicação destas ações se desdobraria também na promoção de santos pretos, que deveriam funcionar como exemplos de virtudes cristãs para os africanos e seus descendentes. O século XVIII viu intensificar-se a ação de franciscanos e carmelitas, experientes hagiógrafos no Ocidente cristão, na difusão de modelos de santidade que pudessem auxiliar na conversão de africanos e seus descendentes em função do incremento do tráfico atlântico. Em 1744, foi publicada a obra Flor Peregrina por Preta, ou Nova Maravilha da graça, descoberta na prodigiosa vida de São Benedito de S. Filadélfio. Religioso 
leigo da Província Reformada da Sicília, das da mais estreita Observância da Religião Seráfica, do frade menor Frei Apolinário da Conceição, que promovia a divulgação da vida de São Benedito. Outra iniciativa ficou ao encargo do padre secular e irmão terceiro franciscano José Pereira Baião, que publicou, em 1726, a História das Prodigiosas Vidas dos Gloriosos Santos Antônio e Benedito, maior honra e lustre da gente preta, também sobre a vida de São Benedito e de Santo Antônio de Categeró.

Diante dos objetivos deste trabalho, destaco o trabalho do carmelita Frei José Pereira de Santana, que, entre 1735 e 1738, publicou Os Dois Atlantes de Etiópia. Santo Elesbão, Imperador XLVII da Abissinia, Advogado dos perigos do mar \& Santa Efigênia, Princesa da Núbia, Advogada dos incêndios dos edifícios. Ambos Carmelitas. O projeto de conversão dos negros colocou Frei José diante da questão da escravidão e de seu lugar na definição de hierarquias no Antigo Regime. De caráter hagiográfico, a obra visava à divulgação das vidas de Santo Elesbão e Santa Efigênia, considerados dois exemplos de virtudes cristãs que teriam vivido em terras africanas. As hagiografias no Ocidente cristão eram reveladoras das expectativas de suas épocas, dotando estes textos de um sentido ideológico. Deste modo, tais narrativas expressavam escolhas e visões de mundo que eram fundamentalmente históricas ${ }^{5}$. Cabe ressaltar que era de igual propósito associar este trabalho à imagem dos carmelitas, já que as ordens religiosas disputavam espaços no interior da Cristandade, principalmente na eficiência de melhor servir aos propósitos da Coroa carreando uma quantidade maior de mercês ${ }^{6}$. Em todas essas obras, os chamados santos pretos estiveram associados aos hábitos das ordens que os promoviam.

Segundo a narrativa de Frei José, Santo Elesbão era natural da Etiópia; $47^{\circ}$ imperador do seu país - no século VI d.C. -, descendia do Rei Salomão e da Rainha de Sabá. Creditou-se a Elesbão a extensão do reino cristão da Etiópia até o lado oposto do Mar Vermelho, impondo-se aos árabes e aos judeus do Iêmen. Entre estes judeus convertidos teria nascido uma rebelião comandada por um certo Dunaan, o qual fora vencido por Elesbão numa expedição punitiva visando restabelecer a ordem. Ao final da vida, o imperador etíope teria renunciado ao trono, doando sua coroa à Igreja e se tornando um anacoreta. Santa Efigênia, assim como Elesbão, pertencia à nobreza. Princesa da Núbia, filha do rei Egyppo, teria se convertido ao 
cristianismo sendo batizada pelo apóstolo Mateus. Indiferente aos prazeres mundanos e aos requintes da corte, tornou-se religiosa fundando um convento. Após a sua conversão e a morte de seu pai, seu tio - Hitarco - teria usurpado o trono do herdeiro legítimo - Efrônio -, irmão de Efigênia, tentando desposá-la para consolidar o seu poder na Núbia. Efigênia teria se recusado a atender aos intentos do rei usurpador, despertando naquele uma profunda ira. Hitarco ordenou que fosse ateado fogo à habitação religiosa onde vivia Efigênia e as religiosas que ela liderava. O convento foi milagrosamente salvo por intercessão da santa. Efigênia foi também figura importante na recuperação do trono por seu irmão, restabelecendo o bom governo na Núbia com a morte do usurpador. Ainda segundo a narrativa, tanto Elesbão quanto Efigênia teriam abraçado a vida religiosa seguindo a regra carmelitana ${ }^{7}$.

As origens africanas e o heroísmo cristão são fatores que procuram ser relacionados à figura de ambos os santos. A Etiópia e a Núbia são apresentadas como terras sempre fiéis ao cristianismo e baluartes desta fé em terras africanas, entretanto, nas duas regiões, o cristianismo quando se fez presente - Etiópia (séc. IV d.C.) e Núbia (séc. VI d. C.) - foi através da Igreja Copta de tradição monofisita, portanto, cismática em relação ao Ocidente. Como afirma Elisabeth Isichei, as conversões da Núbia e da Etiópia ao cristianismo são singularizadas pela inexistência da presença do catolicismo romano ${ }^{8}$.

Frei José construía, deste modo, uma nova memória sobre a África, formalizando a existência de um passado proto-cristão para a Núbia e a Etiópia, além da não menção da tradição copta arraigada à história do cristianismo na região. Esta memória tinha também muito pouca ou nenhuma relação com a África do tráfico atlântico, o que denotava a perspectiva de colocar à disposição dos negros envolvidos naquele tráfico uma outra tradição no que dizia respeito à visão sobre suas terras originárias, ou seja, a África de Elesbão e Efigênia em nada deveria assemelhar-se às terras vistas como gentílicas tocadas pelo tráfico?

Além das origens africanas e do heroísmo cristão relacionado à figura de ambos os santos, Frei José constrói uma associação direta deles com o Carmo, o que, cronologicamente, seria impossível, já que a Ordem foi criada no século XIII. Tal associação denotava a relação que se queria estabelecer entre o Carmo e a proposta de catequese em questão. 
Para além desses fatores, a questão da cor dos santos era outro elemento-chave não só na estruturação do projeto de conversão, como também na explicitação da visão hierárquica que Frei José dava à sua proposta. Elesbão e Efigênia eram pretos. Com vistas a deixar clara esta afirmação, Frei José não só escreve, em 1735, o Sermão dos Santos Pretos Carmelitas, como também insere na hagiografia um Aditamento Apologético a cerca da cor própria e natural do Glorioso S. Elesbão. Este último fora escrito, segundo o próprio frade, em função das dúvidas geradas em torno da cor daqueles oriundos de Axum, pátria do santo. $\mathrm{O}$ não deixar dúvidas quanto à cor dos santos denotava a preocupação com a especificidade da mesma, a qual, segundo Frei José, era um "acidente". Embora os acidentes não corrompessem a essência do ser, eles não deixavam de ser degenerativos. Apesar da cor, Elesbão e Efigênia não estariam inferiorizados na corte celeste, em função de suas almas cristãs. Aqueles que seguissem seus exemplos, apesar do acidente da cor, seriam atingidos também pela graça divina ${ }^{10}$.

Tal discurso tem como base a discussão de São Tomás de Aquino quanto à hierarquia das cores, onde a essência humana é vista como única, criada à imagem e semelhança de Deus, porém, a matéria é individualizada pelos acidentes e entre eles está a cor. Os acidentes, portanto, não só individualizam como também hierarquizam, pois o branco e o preto não estavam na mesma esfera, já que o branco traduz a verdade e o preto é o seu contrário imperfeito. Saliente-se que a elaboração desta discussão, quando feita, não tinha ainda a questão dos africanos como um problema central para o Ocidente cristão, entretanto, os contatos com a África na Época Moderna reavivaram tal problemática contando, inclusive, com a revitalização da Escolástica na sua versão Barroca ${ }^{11}$.

No que concernia às relações sociais no Reino e na América Portuguesa, a cor também era um elemento de construção de hierarquias. Cor invariavelmente designava lugar social. Preto era, principalmente, sinônimo de escravo africano. No caso dos forros expressava um recente passado escravista e ligaçôes com uma origem étnica africana ${ }^{12}$. No contexto do Império português, a questão da cor expressava em parte a naturalidade e a legitimidade das desigualdades e das hierarquias sociais do Antigo Regime ${ }^{13}$.

O discurso de Frei José, ao reforçar a especificidade da cor dos santos, reproduzia uma concepção hierárquica de sociedade, onde até mesmo 
o altar era pensado enquanto um espaço segmentado por diferenças que eram vistas como naturais. A própria existência de um projeto específico de catequese para africanos e seus descendentes reforçava e recriava as diferenças. Neste sentido, a catequese enquanto discurso quer produzir a unidade de procedimentos e crenças, porém, sem deixar de pensar e reproduzir as diferenças. $\mathrm{O}$ que é dado à observação permite constatar que parte deste projeto tem sua eficácia atestada na aceitação destes modelos devocionais por alguns segmentos da população negra. Ao longo do século XVIII, irmandades negras em louvor a Elesbão e a Efigênia foram criadas em diversas áreas da Colônia. A representação imagética dos santos ateve-se, na maioria das vezes, às prescrições de Frei José Pereira de Santana. A relação dos carmelitas com esta difusão foi muito próxima ${ }^{14}$, contudo, as formas desta aceitação não estavam totalmente previstas pelo projeto, pelo menos no que tangia às práticas religiosas cotidianas.

Partindo desta questão, proponho analisar como alguns segmentos das chamadas "gentes de cor" apropriaram-se das imagens de Elesbão e de Efigênia. Tomo como base para esta reflexão a estruturação do culto em irmandades no Rio de Janeiro e em Minas Gerais no século XVIII. Penso que, no contexto da diáspora africana, a questão da identidade foi um fator singular para se compreender historicamente como símbolos cristãos foram resignificados, de forma que sentidos outros tenham sido dados aos pretensos projetos uniformizadores da Igreja. Se por um lado tal processo não anulou completamente a eficácia do projeto de conversão, por outro tornou sua explicação mais complexa, sendo necessário pensar que as reapropriaçóes do mesmo delinearam formas de resistências culturais de africanos e seus descendentes na sociedade colonial.

\section{2 - A Devoção como um símbolo de identidade}

No Brasil colonial, a preocupação com o símbolo devocional assumiu uma proporção bastante significativa. Como afirma Riolando Azzi, a atenção com os protetores celestes denotava a vigência de uma concepção ritualística do mundo, onde os mistérios da natureza e o desconhecimento do funcionamento da própria vida humana conduziam a uma necessidade premente de estabelecer vínculos com o mundo superior ${ }^{15}$, buscan- 
do a todo custo uma identificação com o mesmo. Na África, o processo de cristianização perpetrado pelos europeus, desde o século XVI, já havia tomado os santos como importantes aliados na conversão das populações locais. Segundo John Thornton, um conjunto de idéias religiosas semelhantes entre cristianismo e religiōes africanas tendeu a aprofundar o processo de formação daquilo que o autor conceituou como "catolicismo africano". Entre estas idéias semelhantes estaria a crença num "outro mundo" e na perspectiva de que este pudesse ser revelado. Concomitantemente, acreditava-se na existência de seres que promoveriam o intercâmbio entre "este mundo", material e sensível, e o "outro mundo", imaterial e invisível. Dentro deste quadro de crenças, teria sido possível aos africanos apropriarem-se dos santos católicos muitas vezes identificando-os a divindades locais ou a espíritos ancestrais que poderiam não só fazer revelaçōes sobre o "outro mundo", mas também intervir na resolução de problemas relativos ao cotidiano deste mundo sensível e terreno ${ }^{16}$.

$\mathrm{Na}$ Colônia, uma destas apropriações talvez possa ser identificada no próprio simbolismo do culto de Santo Elesbão e Santa Efigênia. Frei José Pereira de Santana, ao caracterizar as virtudes daqueles santos, recorreu às imagens do sol e da lua para descrevê-los:

... os elevados sólios onde presidiram aquelas duas grandes e flamantes luminárias, Elesbão propriamente como Sol, que por nascer de pais Católicos, dentro da congregação dos Fiéis, em tempo já da Abssínia se haviam desterrado as figuras, símbolos e sombras do Judaísmo, mereceu neste Império a presidência do dia... Efigênia como rutilante Lua, que por aparecer no firmamento da Núbia, quando nos seus países prevaleciam as tenebrosas ignorâncias do Gentilismo, presidio a noite...

Mais ainda que comparados entre si os dois celestes Planetas, um se apelida de maior, e menor o outro... é sem dúvida, que para simbolizarem tão preclaros santos, se equivocam nas luzes, assim como os mesmos Santos se igualam nas virtudes: como se deles e não do outro Sol, nem da outra Lua vaticinasse Isaías, que tinham que ser claridade, semelhantes, iguais nos resplendores... Nem pareça que Elesbão e Efigênia, por causa da cor preta de seus corpos, desmerecem a semelhança... ${ }^{17}$

Os objetivos de Frei José na construção desta associação diziam respeito a afirmação de Elesbão e de Efigênia como luminares da fé católica 
em terras africanas, construindo com isso um exemplo a ser seguido pelos seus devotos ${ }^{18}$. Todavia, pode-se inferir que releituras tenham sido feitas tomando como base este simbolismo. Observando-se a estruturação do culto no Rio de Janeiro setecentista, pode-se ter esta proposição como hipótese. Nesta cidade, a irmandade criada em 1740 unificou o culto aos dois santos, diferente do que demonstrarei adiante com relação a Minas Gerais. Nesta mesma irmandade, como também ficará adiante demonstrado, a maioria dos seus integrantes eram os chamados pretos minas, oriundos da chamada Costa dos Escravos ou Costa da Mina. A identidade mina, no Brasil colonial, encobria uma série de povos oriundos daquela costa, entre eles jejes e iorubas.

Um documento, do século XVIII, de uma congregação existente no interior da Igreja de Santo Elesbão e Santa Efigênia, no Rio, dá conta da existência de alguns destes grupos da Costa dos Escravos encobertos pela identidade mina. Segundo o relatado por um dos autores do documento, em 1748, essa congregação era composta de pretos minas de diversas nações, entre eles daomés, makis ou mahis, ianos, angolins e sabarus ${ }^{19}$. A existência de tais grupos, que se identificam como minas, ligados à irmandade, é uma pista importante para que se possa melhor compreender possíveis reapropriações das figuras de Elesbão e Efigênia e do porque de, no Rio, o culto ter se estruturado em torno do par.

No reino do Daomé, um dos mais importantes da Costa da Mina e representado na Irmandade de Santo Elesbão e Santa Efigênia como um dos grupos fundadores e o mais importante entre os pretos minas na irmandade ${ }^{20}$, era central o culto a Mawu e Lissa, tidos como o par de divindades criadoras. Mawu era o princípio feminino, correspondente à lua, e Lissa o princípio masculino, correspondente ao sol. Segundo a crença, Mawu e Lissa teriam criado o céu e a terra ${ }^{21}$, além de serem a origem das demais divindades (voduns entre os povos jejes). Uma tradição afirma que Mawu e Lissa teriam gerado sete pares de gêmeos, os quais seriam o voduns que representariam os ancestrais de todas as famílias jejes. Segundo Robert Cornevin, uma outra tradição atribui à mãe do rei Tegbessu (1732-1774) a introdução do culto de Mawu no reino, sendo o culto de Lissa conhecido pelo menos desde o século XVII no também reino jeje de Aladá22. De qualquer forma, os chamados pretos minas no Brasil setecentista pode- 
riam ter trazido esta bagagem cultural e não me parece absurdo propor que ela tenha sido utilizada na apropriação do culto de Santo Elesbão e Santa Efigênia, o sol e a lua na narrativa de Frei José. A presença marcante dos daomés entre os minas no Rio de Janeiro e na irmandade em questão pode tê-los impelido a adotar tais santos como seus símbolos devocionais, estabelecendo um diálogo entre os deuses ancestrais africanos e os santos católicos.

Seguindo esta lógica, pode-se constatar que o símbolo devocional na Colônia tinha um papel importante, já que a dimensão pública do catolicismo imprimia a necessidade de sua exteriorização em procissões e festas, identificando o grupo por ele representado. Nas casas, mastros e bandeiras exibiam o santo de devoção. O culto às imagens demandava cuidados expressos na confecção de vestes e na aquisição de adornos para as mesmas ${ }^{23}$. Numa cultura barroca, o papel da dimensão visual reforçava a preocupação de bem representar o emblema da devoção. Decorria daí o cuidado na escolha dos artífices para a confecção das imagens e dos adornos do templo. A Irmandade de Santa Efigênia, em Mariana, confiou a representação de seu orago ao importante entalhador português Francisco Vieira Servas, que trabalhou na região das Gerais na segunda metade do século XVIII. Servas também foi responsável pela construção do altar-mor e dos retábulos do interior da Igreja de Nossa Senhora do Rosário, de Mariana. Nesta mesma igreja ainda trabalharia o importante pintor Manoel da Costa Athayde, que realizou a pintura do forro da capela-mor ${ }^{24}$.

Preocupação semelhante tiveram os devotos de Santa Efigênia da Paróquia do Pilar, em Vila Rica, ao encomendarem o douramento e pintura do altar da santa ao Capitão Gervásio de Souza Lobo, o qual, entre outros trabalhos, fez a pintura do altar-mor da Igreja de Nossa Senhora do Rosário do Pilar de Vila Rica e também pintou quatro painéis sobre os novíssimos do homem que decoravam a sacristia da Matriz de Nossa Senhora do Pilar na mesma cidade ${ }^{25}$. É importante ressaltar, como observa Marcos Aguiar, que nas irmandades negras os gastos, com obras e ornato dos templos, geralmente representaram entre 40 e $60 \%$ das despesas realizadas $^{26}$.

Tais questões permitem considerar a devoção ao santo como uma espécie de emblema a demarcar a identidade do grupo. Durkheim conferiu esta 
função ao totem, que poderia ser comparado aos emblemas heráldicos que conferiam identidade a uma família. Não é minha intenção dar ao santo a mesma caracterização do totem, já que há inúmeras diferenças neste sentido. Todavia, a idéia de emblema traduz o papel de aglutinação para o qual o autor chama a atenção, pois os que pertencem ao grupo se juntam em torno do símbolo, de forma que ele passa a distinguir aquele grupo em relação aos demais ${ }^{27}$.

$\mathrm{Na}$ África a questão simbólica também aparece como significativa. Entre as linhagens mbundu de Angola, Joseph Miller identificou que, desde o século XVII, existiam insígneas que cumpriam o papel de identificação da linhagem. O lunga, por exemplo, era uma dessas insígneas geralmente talhadas na madeira na forma de uma figura humana. Os mbundus atribuíam ao lunga uma série de poderes como o sucesso da agricultura e da própria vida em comunidade ${ }^{28}$. Entre os jejes, na Costa dos Escravos, esta insígnea poderia estar associada a uma árvore sagrada, já que se acreditava que os voduns - espíritos ancestrais - habitavam determinadas árvores. Sendo assim, bosques e florestas eram considerados verdadeiros santuários que guardavam uma memória coletiva ${ }^{29}$. Recolocando a questão da apropriação, talvez seja possível pensar como tal bagagem cultural teria conferido à associação simbólica um papel destacado na releitura do catolicismo pelos diversos povos africanos da diáspora. Leve-se ainda em consideração, recorrendo-se aos dois exemplos citados, que, no século XVIII, a maioria das imagens de santos na Colônia era confeccionada em madeira, o que permitiria um reforço no processo de reapropriação dos símbolos católicos.

Recorrendo a estruturação destas devoções, a questão do simbolismo parece tornar-se nítida. O primeiro capítulo do compromisso da Irmandade de Santo Elesbão e Santa Efigênia, no Rio de Janeiro, materializa o papel emblemático da devoção:

Nós o Juiz, escrivão e mais Irmãos mordomos que este presente ano servimos à Confraria dos Santos desta nossa Irmandade, sita em S. Domingos, desejamos que esta se aumente no serviço de Deus e tenha seus estatutos pelos quais se governe e saiba cada um dos Irmãos as obrigações que lhe competem para que assim se servirá aos Gloriosos Santos, que veneramos e lhe tributamos o maior culto e veneração que pode ser e com nossas devotas assistências e demonstrações se edifiquem os mais fiéis Cristãos, vendo quanto cabe em 
nossa capacidade, fazemos venerar os Gloriosos Santos, ordenamos os estatutos seguintes que com licença alcançamos ${ }^{30}$.

Alguns pontos devem ser observados neste capítulo. O servir aos santos era a primeira obrigação do devoto, ou seja, uma das condições de permanência no grupo. Este servir era expresso pela assistência ao santo, ou seja, o seu culto (dar esmolas, participar das celebraçóes, ser sepultado no templo) e pelo exemplo de cada um, já que o culto e a conduta deveriam edificar os demais fiéis cristãos. A título de comparação é importante ressaltar que, também entre os adeptos do Candomblé, servir ao orixá ou ao santo é a principal obrigação do fiel, traduzindo-se pelas oferendas, pela freqüência ao ritual e por doações à casa de santo o que, simbolicamente, representa igualmente uma submissão diante da fé ${ }^{31}$.

A boa conduta devia estar assentada nos princípios cristãos, os quais deviam espelhar-se na vida do santo que se escolhia para cultuar. $\mathrm{O}$ culto, deste modo, deveria unificar práticas, uniformizando o grupo e dando ao mesmo um perfil. Definidas tais questões, passava-se à exposição das demais cláusulas do estatuto, ou seja, definiam-se outros requisitos de pertença e de permanência no grupo que iam somar-se à obrigação do culto. A manifestação de tal questão no compromisso indicava o grau de consenso em torno da mesma, pois o estatuto máximo da irmandade acabava por refletir um traço da mentalidade do grupo ${ }^{32}$, já que muitas questóes cotidianas eram incorporadas às regras compromissais.

Corroborando esta preocupação que os devotos assumiam com o seu santo de devoção, destaco o exemplo do preto forro, do Gentio da Guiné, Gracia José Manoel. Este, ao redigir o seu testamento, em 1796, declarouse irmão de São Domingos, no Rio de Janeiro, solicitando inclusive ser sepultado na igreja desta irmandade. Ao final do testamento, Gracia disse ser também filiado à Irmandade de São Felipe e São Tiago e, ao que tudo indica, estava em desavença com estes seus confrades, mas não renegando o seu compromisso devocional determinou: "porém, como os irmãos da Irmandade de São Felipe Santiago não fazem caso de mim, não sei porque razão, contudo, como eu tenho devoção com o santo, por isso deixo $4 \$ 000$ de esmola para a dita Irmandade (sic)" ${ }^{33}$. Parece-me um caso claro de valorização do compromisso com a devoção, já que, mesmo diante de uma desavença com os confrades, o compromisso com o culto foi manti- 
do. Ressalte-se também que, como a maior parte dos testamentos era redigida próximo ao momento derradeiro ${ }^{34}$, Gracia não queria deixar de contar com o concurso de mais dois santos de sua devoção e também com as orações de seus confrades, o que, por sua vez, é um flagrante da mentalidade devota que envolvia negros e brancos na Colônia.

No século XIX, a importância simbólica do culto e seu papel na distinção de um grupo foi captada pelo viajante austríaco Emanuel Pohl ao descrever a festa de Santa Efigênia em Traíras - Goiás, em 1819:

Outra festa, com que se alegram o ano inteiro, celebram os negros livres em homenagem a uma santa negra africana de nome Ifigênia. Nessa ocasião fazem tudo que podem para abrilhantarem a festa e superarem os brancos em suas iniciativas semelhantes. Foi celebrada em 24 de junho. De acordo com o uso, duas semanas antes compareceram perante o vigário os delegados dos negros solicitando a licença para a realização da festa. Foi-lhes concedida. Na tarde do mesmo dia, vários negros, vestidos de uniformes portugueses, a cavalo (ornados os animais de campainhas e fitas), primeiramente galoparam um pouco pelas ruas e depois dirigiram-se à igreja. Lá receberam uma bandeira com a imagem de sua Santa e içaram-na num alto mastro diante da porta da igreja como sinal da celebração da festa. Tudo aconteceu sob incessantes disparos de morteiros e mosquetas. Depois cavalgaram em redor da igreja e, em seguida, marchou o cortejo para a igreja paroquial, em cuja praça aberta foram feitas evoluçōes de grande destreza. E, de casa em casa, desejavam votos de felizes festas. Sob o contínuo rufar dos tambores, disparos de espingardas e o ressoar de vários instrumentos nativos do Congo, além de outros sons, seguem os participantes para a casa do imperador (nesta festa também se elege um), onde um negro grita continuamente "Bambi" e o coro em uníssono responde "Domina", o que significa: o rei tudo governa. A horrível gritaria, que chegava até nós, não nos deixou pregar os olhos durante toda a noite ${ }^{35}$.

Pohl faz uma descrição na qual se pode observar o papel do simbolismo do culto em ação. Chamou a sua atenção o galope dos negros que prenunciava a ida à igreja para pegar a bandeira com a imagem da santa, a qual foi colocada em destaque de forma a demarcar o início da festa do grupo. Como chamou a atenção do viajante, as festas dos santos eram momentos relevantes onde se podia observar a importância do culto como fator de distinção. 
Nas irmandades, além do banquete de confraternização entre os irmãos, as festas eram momentos onde se visualizava o prestígio da instituição, estabelecendo-se uma competição entre as agremiações para a realização da melhor festa. Segundo João Reis, o bem celebrar o santo de devoção era uma forma de garantir a proteção no dia-a-dia e garantir o bom destino da alma após a morte através do concurso do orago. $\mathrm{O}$ requinte das homenagens era também uma forma de atrair novos fiéis, colocando em teste a competência lúdica das irmandades. Em síntese, o bem festejar o santo refletia a própria imagem da corporação junto à opinião do públi$\mathrm{Co}^{36}$. Assim sendo, como parte do culto, a festa contribuía também como reforço da identidade do grupo.

Desta forma é possível compreender a importância que as irmandades davam àquelas celebrações, à forma como se colocavam a obrigação de festejar os santos com toda a pompa possível, tendo "de ser os Pregadores (...) sempre os de melhor nota e conceito para que com sua Doutrina afervorem os irmãos", ressaltando-se também o papel da música ${ }^{37}$. Era isto o que determinava o compromisso da Irmandade de Nossa Senhora do Rosário do Pilar de Vila Rica para celebrar os santos abrigados na capela (Nossa Senhora do Rosário, São Benedito, Santo Antônio de Categeró, Santo Elesbão e Santa Efigênia). Neste espírito, entre as décadas de 1740 e 1780, os gastos com as festas dos mesmos santos, também cultuados na capela da Irmandade de Nossa Senhora do Rosário de Antônio Dias de Vila Rica, ficaram entre 40 e $50 \%$ do total de todas as despesas realizadas ${ }^{38}$.

Como via de regra, além do requinte das festas, principalmente nas irmandades negras, o bem festejar estava ligado à dança. Como argumenta Carlos Rodrigues Brandão, analisando a Festa do Rosário em Catalão - sul de Goiás, o "dançar" e o "brincar" para o santo eram vistos como um ato de devoção; a dança era um ato de oração coletiva ${ }^{39}$. Não se pode ignorar que a dança é um importante elemento da cultura religiosa afro-brasileira. Nos terreiros de Candomblé a dança é um dos componentes da liturgia. Ao compor o ritual, a dança reitera hierarquias, além de contar detalhes da história do orixá e dos antepassados. A dança também é um elemento crucial na comunicação do orixá com os iniciados e com os assistentes da cerimônia ${ }^{40}$. Mary del Priore demonstra que, no período colonial, a dança e os batuques eram marcas importan- 
tes da cultura negra nas festas ${ }^{41}$. Deste modo, ao irem às ruas, nas festas e batuques, os festeiros expunham os símbolos de sua devoção, demarcando a importância destes para os seus grupos de pertença.

Em 1764, a Irmandade de Santo Elesbão e Santa Efigênia, no Rio de Janeiro, anexou ao seu compromisso mais cinco capítulos onde era determinada a criação de uma folia. Mesmo aprovando a sua criação, o parecer dado pelo bispo dizia que o termo folia era mal soante aos ouvidos. Segundo Antonio Moraes e Silva, o primeiro significado da palavra folia era dança ao som de pandeiro ou adofe ${ }^{42}$. Numa das definições dadas por Bluteau, folia expressava a realização de danças com instrumentos, com muito ruído, muita extravagância e confusão, que os que andavam nela pareciam doidos ${ }^{43}$. Como Bluteau, o bispo via certamente algo de profano na designação, embora não tivesse se oposto à criação por dizer que era costume dos negros.

A folia dos irmãos de Santo Elesbão e Santa Efigênia previa a criação de um "Estado" ${ }^{44}$, sendo eleitos Imperador, Imperatriz, Príncipe e Princesa. O Imperador foi designado no compromisso como o "Glorioso Santo Imperador”. Previa-se também a eleição, entre os membros da irmandade, de sete reis para o dito "Estado". A folia era obrigada a participar "nas ocasiōes festivas para maior grandeza e aplauso dos ditos santos" 45 .

Analisando este "Estado" de folia, Mariza Soares identificou na sua criação a oportunidade de resolução de conflitos entre os grupos dentro da irmandade. Segundo a autora, a eleição dos reis permitia que as identidades étnicas aflorassem, partilhando-se então o poder entre os diversos segmentos que compunham a associação ${ }^{46}$. Tal questão parece explicitarse de uma forma mais clara quando se observa que a estrutura do "Estado" de folia poderia evocar algumas estruturas políticas existentes na Costa dos Escravos de onde provinham os pretos minas fundadores da Irmandade de Santo Elesbão e Santa Efigênia no Rio de Janeiro.

No poderoso reino de Oió que dominou aquela costa entre os séculos XVII e XIX, desde o seiscentos é possível constatar que havia uma estrutura administrativa onde existiam as figuras dos chamados sete oió mesis, eram eles chefes das linhagens aristocráticas da cidade e auxiliares do rei na gestão da mesma. É possível, como adverte Alberto da Costa e Silva, que o poder do rei, no século XVIII, estivesse menos condicionado por essa estrutura ${ }^{47}$, todavia, a existência da mesma esclarece quanto a necessidade da mediação 
dos conflitos entre os grupos formadores do reino. $\mathrm{O}$ também reino ioruba de Queto possuía uma estrutura semelhante, sendo o conselho real composto pelos chamados Oloiês escolhidos entre os principais chefes de família. No auge do reino este conselho chegou a ser composto por 70 membros $^{48}$.

A preponderância do reino de Oió ${ }^{49}$ na Costa dos Escravos, no século XVIII, inclusive sobre o poderoso reino do Daomé, provavelmente tornou tais estruturas conhecidas mesmo entre os reinos que não eram de origem ioruba. No Brasil, o contato entre iorubas e jejes foi constante ${ }^{50}$, além de serem ambos os grupos identificados como minas. Deste modo, não parece ser estranho que este modelo de organização dos grupos de linhagem pudesse ser conhecido pelos pretos minas da Irmandade de Santo Elesbão e Santa Efigênia. Tanto que o próprio compromisso da irmandade frisava a necessidade de serem eleitos "somente os ditos sete Reis para o perfeito ato do Imperador" ${ }^{51}$.

Todavia, além destes fatores, gostaria de chamar a atenção para a questão da manipulação dos símbolos devocionais como um meio de resolução dos conflitos. É importante ressaltar que a folia de Santo Elesbão e de Santa Efigênia instituía um "Estado Imperial”. Elesbão, como narrou Frei José Pereira de Santana, foi Imperador da Etiópia e Efigênia Princesa da Núbia. Parece-me que festejar aqueles santos por meio de um "Estado Imperial" refletia dois aspectos: o primeiro dizia respeito ao caráter de inversão social promovido pelas festas negras; o segundo era tomar de empréstimo das vidas de Elesbão e de Efigênia parte da estrutura organizacional da folia. Outra alusão que me parece explícita era o fato de o Imperador da folia ter o título de "Glorioso Santo Imperador", título pelo qual várias vezes Frei José identificou Elesbão na hagiografia. A eleição de reis adjuntos também se aproxima muito da narrativa que Frei José fez dos domínios de Elesbão:

Imensos parecem os Reinos de que este Monarca foi senhor; pois se não dilatou o seu Império só pelo interior da África, mas também dominou uma considerável parte da Ásia, estendida além do Mar Vermelho para a banda do Oriente.(...) Divide-se em trinta e cinco Reinos Principais, e muitas Províncias, umas isentas e outras ao mesmo Império subordinadas. (...) Em alguns destes Reinos residiam testas coroadas, que ao supremo Imperador reconheciam obediência. (...) A razão de conservarem este privilégio é por- 
que, pretendendo um Imperador a conquista destes Reinos, logo os seus Soberanos (aos quais intitulavam Reis) se sujeitaram à Coroa da Etiópia sem repugnância; fazendo talvez da necessidade obséquio, por evitarem os efeitos da violência ou estragos da vingança ${ }^{52}$.

Não seria demais supor que estas qualidades conciliatórias de Elesbão, mantendo sob seu domínio inúmeras testas coroadas, tivessem, em algum momento, feito parte de algum sermão pregado num dia de festa ou que tivessem sido lidas por membros da irmandade. Efetivamente, esta narrativa pode reforçar o argumento de Mariza Soares sobre o "Estado Imperial” como forma de solucionar conflitos, já que os reis, segundo Frei José, aceitaram o domínio de Elesbão a bem da ordem. Por outro lado, a narrativa também reforça a argumentação da importância da devoção na constituição da identidade do grupo, pois só se recorre ao símbolo para resolver conflitos se, minimamente, o grupo se identifica com o mesmo, conferindo-lhe o poder de avalizar um pacto.

A questão da catequese, no que tange à sua eficácia e a reapropriação dos símbolos católicos pelas populações convertidas, também pode ser recolocada, já que o "Estado Imperial" recorre à história dos santos com o propósito de solucionar questôes cotidianas dos fiéis. Ronaldo Vainfas e Marina de Mello e Souza, ao trabalharem a questão da catolização do Reino do Congo entre os séculos XVI-XVIII, demonstram que o movimento antoniano, embora considerado herético pela Igreja, denotava um êxito da conversão e, ao mesmo tempo, manifestava uma reapropriação do simbolismo cristão para afirmar crenças caras à religiosidade banto, como a crença no poder dos mortos ${ }^{53}$.

A recuperação do "Estado Imperial" e das realezas na irmandade, além de denotarem a questão da eficácia da catequese, pode também chamar a atenção para a recuperação de fragmentos da memória africana dos irmãos, através dos símbolos cristãos. Um primeiro momento deste processo pode ser percebido na questão dos reis que assessorariam o Imperador na folia. Tal fato, como já ressaltei, poderia relacionar-se à memória de situaçōes políticas da própria África, onde era comum o fato de linhagens governantes se imporem e cobrarem tributos de chefes de linhagens subordinadas. $\mathrm{O}$ segundo momento que se pode identificar neste processo de reconstrução da memória está nos próprios rituais de formação de impérios, realezas e 
coroaçôes. Como analisou Marina de Mello e Souza, a eleição de reis negros representou um processo de recriação de tradições onde se mesclaram fragmentos de uma memória africana e elementos da cultura católica européia ${ }^{54}$.

Há que se reforçar que a coroação e a realeza são elementos importantes na constituição de identidades por africanos e seus descendentes no Brasil escravista. As raízes africanas da coroação de reis negros recuperam traços de uma identidade tribal que se recoloca imediatamente após a importância conferida aos laços de linhagem. A união de diversos grupos familiares em torno de um rei, eleito pela comunidade, reforçava o sentido de pertencimento a um grupo e, no quadro da diáspora africana, a recriação destas tradições funcionou como uma forma de sobrepujar a desagregação social promovida pelo tráfico atlântico ${ }^{55}$.

Mais uma vez a Irmandade de Santo Elesbão e Efigênia, no Rio de Janeiro, configura-se como um locus privilegiado para se observar este processo. Em 1762, a Congregação dos Pretos Minas do Reino Maki ou Mahi, localizada dentro da irmandade, elegeu como rei o capitão Inácio Gonçalves do Monte. Este era tido como um verdadeiro Maki, tendo dado rumos à congregação que se dizia fundamentalmente católica ${ }^{56}$.

Cheguei à história do Capitão Inácio Gonçalves do Monte localizando seu testamento no Arquivo Arquidiocesano do Rio de Janeiro. Este documento contém outras informações, as quais não foram mencionadas no documento da Congregação Maki analisado por Mariza Soares. A análise do testamento de Inácio permite compreender um pouco melhor a razão do seu prestígio em meio a sua comunidade. Nascido na Costa da Mina, era ele oficial de barbeiro com oficina aberta; além de emprestar dinheiro, fato este que registrava em um livro de 75 folhas ao qual faz menção no seu testamento. Neste mesmo livro dizia anotar o dinheiro que os seus patrícios entregavam para que ele guardasse, provavelmente o dinheiro que se encontrava no cofre da congregação analisada por Mariza Soares. Isto demonstrava o seu papel de liderança e o seu prestígio junto aos seus conterrâneos. Além de ser credor de "várias pessoas", como mencionou, Inácio declarou ter como patrimônio 10 escravos, vidro (sic), prata e móveis de casa. Ao que tudo indica, o capitão era um homem forro, economicamente, bem sucedido naquela sociedade, entretanto, pareceme também que o prestígio e a liderança de Inácio eram reforçados pelo que declarou no início de seu testamento: era ele neto de um certo "Efuí 
Agoan”, segundo Inácio, um bem conhecido rei no Reino do Maki na Costa da Mina ${ }^{57}$.

Neste sentido, a eleição de Inácio confirmaria o que defende Marina de Mello e Souza quanto ao fato de a escolha de reis, nas Américas, ter também recaído sobre o critério de preferências por chefias tribais dos lugares de origem ${ }^{58}$. Embora Inácio não tivesse sido rei, o seu avô o fora. E isto, de certo modo, pode ter influenciado a escolha de seus compatriotas.

Ao tornar-se rei de sua congregação católica, Inácio efetivamente estabelecia, para ele e no imaginário do grupo que o elegeu, laços com a realeza existente no Reino do Maki. O sentido da realeza na congregação estava-se assentando, deste modo, dentro da perspectiva católica, pois se dava dentro de uma irmandade, mas ao mesmo tempo prestava-se a recriar tradições de uma África, naquele momento, bastante distante para aqueles homens. Desta forma, o sentido do "Estado Imperial" de folia sintetizava a devoção católica e as recordaçōes ${ }^{59}$ da África, recolocando-se novamente o papel do culto e da coroação de um rei como elementos de reconstrução da memória e da própria identidade do grupo.

Nesta perspectiva não deve ter sido por acaso que a lenda do Chico Rei, em Minas Gerais, associou o "Estado" formado por Francisco e seus conterrâneos africanos com o patronato de Santa Efigênia ${ }^{60}$. A lenda fala de um rei negro que não contestou a ordem vigente, tornou-se católico a ponto de construir uma capela em homenagem à santa que acreditava ter ajudado a ele e aos seus súditos conseguirem a liberdade. Santa Efigênia, neste caso, também sintetizava a introjeção da mensagem católica e a possibilidade de, mesmo distante da África, reconstruírem-se tradições ligadas a uma memória ancestral. É bastante provável que a figura lendária do Chico Rei guarde ligação com a figura do Rei Negro que tanto temor causava às autoridades coloniais no setecentos. O próprio D. João V em carta ao Governador da Capitania de Minas Gerais, em 1725, referia-se com preocupação à existência de reis entre os Angolas e Minas na capitania. O receio era sempre relativo à possibilidade destas lideranças estarem conduzindo rebeliōes entre os escravos ${ }^{61}$.

Em que pese não se saber precisamente quando a lenda passou a ser veiculada, a narrativa em torno do Chico Rei recoloca a importância da devoção como um elemento de identidade grupal, pois tanto Elesbão, no Rio, quanto, Efigênia, em Minas, foram acionados enquanto símbolos 
que possibilitaram o encontro de duas tradiçôes: a cultura católica e as culturas africanas. E, enquanto símbolos deste encontro, passaram a distinguir um segmento populacional tanto em relação à população negra, quanto em relação à população branca naquelas localidades.

Robert Markus, ao tratar do fim do Cristianismo Antigo, analisa o papel do culto aos mártires enquanto um elemento de construção da identidade cristã. Segundo este autor, no século IV, o culto possibilitou à comunidade cristã construir um discurso histórico baseado na memória dos mártires. Foi o resgate desta memória que, em última instância, possibilitou a construção de uma identidade cristã ${ }^{62}$. Acredito ser possível pensar este processo de construção da memória e construção de identidades para o culto de Elesbão e de Efigênia no Brasil setecentista. Este culto, na intercessão do projeto de catequese e na vivência religiosa dos negros, possibilitou o diálogo das tradições católica e africanas, expressando a construção de novas memórias e novas identidades por africanos e seus descendentes.

\section{3 - Devoção e grupos étnicos}

Ao discutir a relação entre religião e identidade étnica, Manuela Carneiro da Cunha argumenta que, na utilização do conceito de etnicidade, a identificação dos símbolos manipulados pelos grupos é um passo importante para diferenciá-los. Segundo a autora, cada grupo étnico pode dispor de vários símbolos, no entanto, estes têm de ser inteligíveis a todos os grupos de forma a que se possa, efetivamente, construir um padrão de identificação ${ }^{63}$. O que pretendo, a partir destas colocações e dando continuidade à discussão precedente, é compreender como os símbolos devocionais podem ser vistos enquanto manifestações da construção de identidades étnicas. Não estou afirmando que o culto dos santos encerre em si todo o processo de identificação étnica, mas penso ser possível vê-lo como um dos elementos a compor esta identidade.

No que diz respeito à questão da devoção nas irmandades negras, trabalhos vêm demonstrando a possibilidade do estudo destas instituições enquanto espaços de estruturação de identidades étnicas ${ }^{64}$. Ao congregarem-se em torno dos santos patronos, africanos e seus descendentes estruturaram laços de solidariedade que permitiram a conquista de graus de relativa autonomia em meio às agruras do sistema escravista. 
O grande problema, no entanto, consiste na definição desses grupos étnicos. Desde a década de 1960, muito em função do processo de Descolonização, as ciências sociais intensificaram os debates em torno das questôes étnicas. Fredrik Barth, Abner Cohen e muitos dos seus seguidores foram responsáveis por uma revisão profunda dos conceitos de etnicidade. Abandonou-se a concepção de que era possível o encontro de unidades étnicas no seu sentido original, passando-se a se preocupar com a identificação da diversidade do grupo em sua organização e não como os traços culturais eram distribuídos. Deste modo, o grupo étnico passou a ser visto não como uma unidade natural/pura, mas sim como uma unidade que, dotada de uma cultura, empreende um processo de reconstrução de suas formas de organização em meio às condiçōes históricas vividas ${ }^{65}$.

A diáspora promovida pelo tráfico atlântico colocou para a historiografia brasileira questóes muito semelhantes quanto ao processo de formação e definiçãao dos grupos étnicos. Como analisou Mary Karasch, as naçôes africanas que chegaram ao Brasil, na maioria das vezes, ostentaram nomes classificatórios impostos pelo tráfico, os quais se referiam, na quase totalidade, aos portos de embarque dos cativos. Essas naçóes não correspondiam, efetivamente, aos grupamentos originais daqueles homens ${ }^{66}$.

João Reis, no entanto, talvez tenha sido um dos primeiros a mostrar como estas denominações do tráfico foram reapropriadas pelos escravos e ex-cravos de forma a constituírem unidades étnicas formadas em meio aos embates políticos e culturais vigentes na sociedade escravista brasileira ${ }^{67}$. Mariza Soares preferiu compreender os nomes classificatórios do tráfico enquanto grupos de procedência, admitindo que estes poderiam recriar, no ambiente da escravidão, relaçóes múltiplas de solidariedade, tendo nas irmandades um dos espaços privilegiados de manifestação ${ }^{68}$.

$\mathrm{Na}$ documentação das irmandades, na maioria dos casos, o que é possível identificar são as nações definidas pelo tráfico. Os escrivães responsáveis pelos livros de assento dos irmãos, quando faziam menção à origem do afiliado, utilizavam freqüentemente as denominaçôes "mina", "angola”, "congo", entre outras. Pode-se observar, a exemplo do que argumenta João Reis, que as denominações do tráfico foram reapropriadas e utilizadas pelos negros de forma a se organizarem política e culturalmente. Deste modo, penso poder compreender as nações do tráfico enquanto grupos étnicos organizacionais, a exemplo do que faz Manuela Cunha com base na leitura de Abner Cohen ${ }^{69}$. 
Diante destas questões, é possível compreender como estes grupos, no interior das irmandades, acionaram os símbolos devocionais enquanto um dos elementos de construção de suas respectivas identidades, já que, como afirmam Manuela Cunha e Roberto Cardoso de Oliveira, a religião é um dos elementos importantes a ser observado no processo de constituição dos grupos étnicos ${ }^{70}$. Desta forma, acredito que se possa pensar na recriação de símbolos étnicos identitários, a exemplo do lunga dos mbundu e dos voduns jejes, resignificados na imagem dos santos católicos.

No Rio de Janeiro, desde 1740, quando da fundação da Irmandade de Santo Elesbão e Santa Efigênia, é possível perceber a preponderância dos pretos minas na constituição e no controle da irmandade. Ao passar a provisão de instituição da irmandade e confirmação do seu compromisso, o escrivão da Câmara Eclesiástica já afirmava claramente a preeminência dos minas no processo de criação da associação:

Provisão que $S$. Ex ${ }^{a}$ Revr $^{a}$ há por bem conceder aos pretos minas da freguesia da Candelária para se formarem em Irmandade. D. Frei Antônio de Guadalupe por mercê de Deus e da Santa Sé Apostólica Bispo do Rio de Janeiro e do Conselho de S. Majestade a quem Deus guarde etc. Fazemos saber que atendendo-nos ao que por sua petição reto (sic) nos escrevam a dizer os pretos minas Irmãos da Irmandade de S. Elesbão e Efigênia da Igreja de $S$. Domingos desta cidade que eles a tinham ereta e para melhor se governarem nela e maior aumento da mesma e do serviço de Deus fizeram o seu compromisso que apresentam ..... ${ }^{71}$

Parece ficar claro que, na visão da Câmara Eclesiástica, os minas eram os grandes impulsionadores da organização da devoção em irmandade. $\mathrm{O}$ capítulo 10 do compromisso, no entanto, mostra que outros grupos estavam presentes na organização da devoção, enquanto que alguns foram, inicialmente, excluídos:

Antes que o Juiz e mais oficiais da mesa desta Santa Irmandade queiram admitir e fazer assentar a qualquer pessoa que o queira ser sendo preto ou preta, primeiro examinarão com exata diligência a terra e nação de onde vieram e achando serem naturais e que são oriundos da Costa da Mina, Cabo Verde, Ilha de S. Tomé ou de Moçambique logo se fará assento nela

.... e de nenhuma sorte se admitirão pretas de Angola, nem crioulas, nem cabras ou mestiços, e o Juiz e mais oficiais e os Irmãos da Mesa que ao 
contrário fizerem acabando o ano de sua ocupação não tornarão a servir coisa alguma na dita Irmandade de que se fará termo pelo Juiz oficiais e mais Irmãos de Mesa que logo lhe suceder restituindo outro sem os ditos Irmãos que admitam os ditos pretos e pretas Angolas crioulos ou cabras tanto homem como mulheres a cada um o que deram de sua entrada para que fique de nenhum efeito seus assentos de que se fará declaração à margem dos livros deles ${ }^{72}$.

O capítulo demonstra, efetivamente, como as denominações do tráfico eram incorporadas pelos grupos e utilizadas como critérios de diferenciação. Além disso, pode-se observar as alianças que os minas construíram no sentido de estruturar a irmandade. Os grupos mencionados no compromisso eram minoria entre as nações africanas existentes no Rio de Janeiro, já que o tráfico para o porto desta cidade, desde a segunda metade do século XVII, vinha privilegiando os portos da África Centro-Ocidental. Neste sentido, os chamados grupos bantos constituíam a maioria dos africanos existentes na cidade.

A composição, deste modo, indicava alianças que foram feitas segundo as determinações das condições históricas locais ${ }^{73}$. Não representados em outras irmandades, estes grupos resolveram unir-se em torno do culto a Elesbão e a Efigênia, um dos símbolos de sua diferenciação entre os demais grupos negros da cidade. É também interessante observar que a união se faz basicamente com grupos oriundos da África Ocidental, a exceção dos moçambiques. Robert Slenes analisou para o Rio de Janeiro, na primeira metade do século XIX, a possibilidade de formação de uma proto-nação banto calcada nas proximidades lingüísticas e nas experiências comuns da travessia do Atlântico ${ }^{74}$. Talvez, para os grupos presentes na irmandade, seja possível pensar uma aliança em torno do fato de serem minorias na cidade e também nas experiências da travessia do Atlântico, pois, como afirmam Mintz e Price, esta travessia demonstrou-se como um dos momentos privilegiados para o estabelecimento de solidariedades entre os africanos que aportaram nas Américas ${ }^{75}$.

A essência exclusivista do capítulo 10 do compromisso da irmandade foi contestada, em 1767, quando o documento foi submetido à apreciação da Mesa de Consciência e Ordens. Por determinação real deveriam ser retirados do compromisso os impedimentos à admissão dos crioulos, cabras e pretos de Angola. Esta exigência, ao que tudo indica, estava fundamentada 
na política portuguesa de mistura dos diversos grupos africanos de forma a evitar revoltas ${ }^{76}$. Todavia, como em outros lugares da colônia, a determinação na prática não acabou com a preponderância dos minas dentro da irmandade.

Infelizmente, não foram preservados os livros de assento dos irmãos desta irmandade para o século XVIII, o que impossibilita acompanhar o ritmo das filiações. Tem-se, no entanto, os registros de óbito da freguesia onde estava situada a igreja da irmandade. Através deles é possível perceber os grupos que, preferencialmente, escolheram a igreja da irmandade para aí serem sepultados, isto levando-se em consideração a prática dos sepultamentos ad sanctos que, para garantir a salvação da alma, eram realizados próximo aos altares dos santos de devoção para que estes intercedessem pela alma do fiel ${ }^{77}$.

De um levantamento de 1782 registros de óbitos de negros, sepultados na freguesia da $\mathrm{Se}^{78}$, o quadro abaixo indica os sepultamentos que foram realizados em igrejas de irmandades de negros. Procurando comparar os sepultamentos realizados na Igreja de Santo Elesbão e Santa Efigênia com as demais igrejas de negros, recorto os dados a partir de 1751, ano em que esta igreja começou a aparecer nos registros como local de sepultamentos.

\begin{tabular}{|l|c|c|}
\hline IGREJAS & No & $\%$ \\
\hline Nossa Senhora do Rosário & 388 & 31,5 \\
\hline N. S. da Conceição e Boa Morte & 200 & 16,3 \\
\hline São Domingos & 198 & 16,1 \\
\hline N. S. da Lampadosa & 138 & 11,2 \\
\hline Senhor Bom Jesus & 125 & 10,2 \\
\hline Santo Elesbão e Santa Efigênia & 80 & 6,5 \\
\hline N. S. do Parto & 53 & 4,3 \\
\hline São Gonçalo Garcia & 31 & 2,5 \\
\hline N. S. das Mercês & 7 & 0,6 \\
\hline São Jorge & 6 & 0,5 \\
\hline N. S. Santana & 4 & 0,3 \\
\hline TOTAIS & 1230 & 100,0 \\
\hline
\end{tabular}

Quadro 1 - Sepultamentos em igrejas de irmandades negras na Freguesia da Sé do Rio de Janeiro (1751-1810)

Fonte: AARJ - Livros de Óbitos de Testamentos das Freguesias da Sé e Santíssimo Sacramento (1701-1812) 
A preponderância do Rosário explica-se pelo fato de ser a devoção mais popular entre os negros e ser a irmandade de negros mais antiga da cidade, todavia, é preciso levar em conta que, entre 1737 e 1808, o Rosário foi matriz e Sé catedral, isto implica dizer que, como matriz, a igreja tinha covas mais baratas do que aquelas oferecidas estritamente pelas igrejas de irmandades, além do que as covas destas igrejas eram destinadas prioritariamente para os irmãos ${ }^{79}$. Tais fatos podem ajudar a compreender o maior número de sepultamentos naquela igreja.

A Igreja dos santos Elesbão e Efigênia atraía o sexto contingente de devotos entre as irmandades negras. Das igrejas que a precedem no Quadro 1 , foi a que mais tardiamente começou a receber sepultamentos, além de ter sido, entre elas, a última a receber provisão definitiva, em 1754. Embora não sendo a igreja mais procurada, não se pode desprezar a sua importância entre as igrejas de irmandades de negros na cidade, pois significava para os seus freqüentadores um espaço importante de vivência da devoção e expressão de suas identidades.

Em termos das condiçôes sociais, dos 80 irmãos sepultados na igreja de Santo Elesbão e Santa Efigênia, 31 eram escravos, 34 eram forros, um era livre e 14 deles os registros não informam a condição. Em termos dos grupos étnicos, 39 registros mencionaram a procedência dos irmãos. $\mathrm{O}$ quadro abaixo mostra como eles se distribuíram.

\begin{tabular}{|l|c|c|}
\hline ORIGENS & No & $\%$ \\
\hline África Ocidental & & \\
\hline Mina & 27 & 69,2 \\
\hline África Centro-Ocidental & & \\
\hline Angola & 04 & 10,2 \\
\hline Congo & 01 & 2,6 \\
\hline Benguela & 01 & 2,6 \\
\hline Rebolo & 01 & 2,6 \\
\hline Mocumbe & 01 & 2,6 \\
\hline Nascidos na Colônia & & \\
\hline Crioulos & 04 & 10,2 \\
\hline TOTAIS & 39 & 100,0 \\
\hline
\end{tabular}

\section{Quadro 2 - Origens dos sepultados na Igreja de Santo Elesbão e Santa Efigênia no Rio de Janeiro (1751-1810)}

Fonte: AARJ - Livros de Óbitos e Testamentos das Freguesias da Sé e Santíssimo Sacramento (1701-1812) 
Angolas e crioulos, preteridos na primeira versão do compromisso, buscaram sepultura na igreja, atingindo percentuais consideráveis, todavia, é impossível negar a maior identificação dos minas com a igreja, identificação esta que perdurou no século XIX. Para o período entre 1843 e 1889 é possível encontrar o livro de assentos dos irmãos. Em pesquisa anterior, pude constatar que, entre os africanos que se filiaram à irmandade, os minas representavam $46,6 \%$ do total, enquanto angolas e crioulos representavam respectivamente $5,8 \%$ e $4,0 \%{ }^{80}$. Deste modo, parece ser possível afirmar que, embora não exclusivamente, no Rio de Janeiro, o culto a Santo Elesbão e Santa Efigênia estava identificado a um segmento dos pretos minas, os quais estabeleceram nesta devoção um dos sinais diacríticos que os diferenciava de outros grupos étnicos negros da cidade.

Em Minas Gerais, no entanto, constatar-se-á que a simbologia daqueles santos foi trabalhada de forma a identificar outros grupos que não os pretos minas, o que demonstra o caráter histórico e dinâmico na constituição dos grupos étnicos e na difusão do culto aos santos. $\mathrm{Na}$ opinião de Marcos Aguiar, não se encontra, em Minas, dentro das irmandades, clivagens étnicas entre as populaçôes africanas na organização das devoçôes. Segundo este autor, a clivagem essencial deu-se entre crioulos e africanos $^{81}$. A questão, no entanto, parece-me bem mais complexa, merecendo uma suspensão de juízo sobre a mesma.

Começo a análise por Mariana, onde o culto a Santa Efigênia estava organizado sozinho em uma irmandade na Igreja do Rosário. Devo salientar que, pelo fato de o culto não ser único no templo, concluí que seria melhor traçar uma comparação entre as três irmandades existentes na Igreja do Rosário, de forma a tornar mais nítidos os dados referentes ao culto de Efigênia. Tomando como base as informaçôes dos livros de assentos de irmãos, constata-se que, dentre os 184 registros analisados, $42 \%$ dos irmãos eram escravos e $11 \%$ eram forros; $47 \%$ dos registros não informam a condição dos afiliados. Ressalte-se que o livro da Irmandade de Santa Efigênia é o que apresenta o conjunto de registros mais incompletos. Destes 184 registros, a maioria deles $(155-84,2 \%)$ cobre a primeira metade do século XVIII, concentrando-se entre os anos de 1737 e 1748.

$\mathrm{Na}$ Irmandade de São Benedito, dos 441 registros de base, 52,9\% identificam irmãos escravos e 23,8\% forros; $23,3 \%$ dos registros não mencionam a condição dos irmãos. Na Irmandade de N.S. do Rosário, entre os 875 registros considerados, a informação é de que 65,5\% dos irmãos 
eram escravos, $0,3 \%$ eram coartados e $26,1 \%$ eram forros; $8,1 \%$ dos registros não fazem menção à condição dos irmãos ${ }^{82}$. Os quadros abaixo distribuem os irmãos das três associações segundo suas origens.

Quadro 3 - Origens dos irmãos de Santa Efigênia de Mariana (1737-1810)

\begin{tabular}{|l|c|c|}
\hline ORIGENS & No & $\%$ \\
\hline África Ocidental & & \\
Mina & 01 & 6,25 \\
Cabo Verde & 01 & 6,25 \\
\hline África Centro-Ocidental & & \\
Benguela & 02 & 12,5 \\
\hline Nascidos na Colônia & 12 & 75,0 \\
\hline Crioulo & 16 & 100,0 \\
\hline TOTAIS
\end{tabular}

* 0 livro menciona a origem de 16 irmãos.

Fonte: AEAM - Assento de Irmãos da Irmandade de Santa Efigênia de Mariana (1737-1810)

Quadro 4 - Origens dos irmãos de São Benedito de Mariana (1727-1810)

\begin{tabular}{|l|c|c|}
\hline ORIGENS & No & $\%$ \\
\hline África Ocidental & & \\
Mina & 39 & 41,0 \\
Courana & 14 & 14,7 \\
Cobu & 02 & 2,1 \\
Cabo Verde & 02 & 2,1 \\
Sabaru & 01 & 1,1 \\
Nagô & 01 & 1,1 \\
\hline África Centro-Ocidental & 18 & 18,9 \\
Angola & 04 & 4,2 \\
Benguela & 02 & 2,1 \\
Rebolo & 01 & 1,1 \\
Ganguela & 01 & 1,1 \\
Congo & 01 & 1,1 \\
Mocumbe & & \\
\hline Nascidos da Colônia & 09 & 9,4 \\
Crioulo & 95 & 100,0 \\
\hline TOTAIS
\end{tabular}

* 0 livro menciona a origem de 95 irmãos.

Fonte: AEAM - Assento de Irmãos da Irmandade de São Benedito de Mariana (1727-1842) 
86 • Anderson José Machado de Oliveira

Quadro 5 - Origens dos irmãos de N. S. do Rosário de Mariana (1747-1810)

\begin{tabular}{|c|c|c|}
\hline ORIGENS & No & $\%$ \\
\hline \multicolumn{3}{|l|}{ África Ocidental } \\
\hline Mina & 183 & 33,0 \\
\hline Courana & 65 & 11,6 \\
\hline Fom & 25 & 4,5 \\
\hline Cobu & 11 & 2,0 \\
\hline Courá & 09 & 1,6 \\
\hline Cabo Verde & 09 & 1,6 \\
\hline Sabaru & 08 & 1,4 \\
\hline Nagô & 04 & 0,7 \\
\hline São Tomé & 01 & 0,2 \\
\hline Dagomé & 01 & 0,2 \\
\hline \multicolumn{3}{|l|}{ África Centro-Ocidental } \\
\hline Angola & 116 & 21,0 \\
\hline Benguela & 16 & 3,0 \\
\hline Congo & 07 & 1,2 \\
\hline Rebolo & 02 & 0,3 \\
\hline Cabundá & 01 & 0,2 \\
\hline Ganguela & 01 & 0,2 \\
\hline Mocumbe & 01 & 0,2 \\
\hline \multicolumn{3}{|l|}{ África Oriental } \\
\hline Moçambique & 02 & 0,3 \\
\hline \multicolumn{3}{|l|}{ Nascidos na Colônia } \\
\hline Crioulo & 64 & 11,4 \\
\hline \multicolumn{3}{|l|}{ Não Identificadas } \\
\hline Lada & 19 & 3,4 \\
\hline Tibu & 04 & 0,7 \\
\hline Goimeno & 02 & 0,3 \\
\hline Maçangana & 01 & 0,2 \\
\hline Cravari & 01 & 0,2 \\
\hline Ladana & 02 & 0,2 \\
\hline Xambá & 01 & 0,2 \\
\hline Bacá & 01 & 0,2 \\
\hline TOTAIS & 557 & 100,0 \\
\hline
\end{tabular}

* O livro menciona a origem de 557 irmãos.

Fonte: AEAM - Assento de Irmãos da Irmandade de N.S. do Rosário de Mariana (17471931). 
Embora as grandezas absolutas não sejam proporcionais entre as três irmandades, é possível perceber, por amostragem, que havia, nesta igreja, uma preferência dos crioulos pela irmandade de Santa Efigênia, pois mesmo estando representados nas outras irmandades, proporcionalmente, acabaram optando mais por esta última, no contexto desta igreja.

Foi nítida também a opção dos pretos minas de Mariana pelos outros oragos do templo, principalmente, por São Benedito, onde a proporção deste grupo foi maior, embora também majoritário com relação à Nossa Senhora do Rosário. Destaque-se que, no Rio, o culto a São Benedito estava unido ao do Rosário, formando uma única irmandade, onde os angolas e crioulos eram maioria. Em Minas Gerais, contrariamente ao Rio, os pretos minas foram maioria entre os africanos, pelo menos até o final do século XVIII, quando também começaram a ser superados pelos grupos oriundos da África Centro-Ocidental ${ }^{83}$. Os angolas, segundo maior grupo representado em São Benedito e em Nossa Senhora do Rosário, não parecem ter optado pela devoção de Santa Efigênia.

Aparentemente, no que se refere às clivagens étnicas, a divisão entre crioulos e africanos era a mais evidente, todavia, esta aparência, a meu ver, escondia disputas internas entre estes grupos pelo controle das irmandades e pela definição de hierarquias entre eles. Uma variante importante para se identificar tais disputas é observar a distribuição dos cargos. É importante salientar que, embora a ocupação dos cargos nas irmandades fosse por eleição, esta, por sua vez, não assumia a feição de participação por sufrágio universal. Os componentes da Mesa Administrativa eram indicados por grupos de pressão que se constituíam no interior das associações. Desta forma, os grupos dominantes ou mais organizados tinham condiçôes de controlar o maior número de cargos. Da mesma forma, esta capacidade de controle e indicação dependia também da construção de alianças com outros grupos ${ }^{84}$.

Em Mariana, na Irmandade de Santa Efigênia, o livro de assentos menciona a ocupação de cargos em 25 registros. Na definição dos grupos foi possível identificar que duas crioulas ocuparam cargos de juíza, uma preta forra Cabo Verde também serviu como juíza, duas mulheres de cor branca serviram como juízas, uma mulher reconhecida como "Dona” serviu como juíza e um homem com título de "Reverendo Doutor" ocupou os cargos de escrivão e tesoureiro. 
Na Irmandade de São Benedito, a composição entre os grupos parecia ser outra. O livro de assentos faz menção a 17 pessoas que ocuparam cargos. Os grupos étnicos explicitamente mencionados como ocupantes de cargos foram: mina (três), courana (dois) e crioulo (um). Os dados restantes não fazem qualquer menção que permita a identificação da origem dos demais ocupantes de cargos.

$\mathrm{Na}$ Irmandade de N.S. do Rosário, o livro de assentos identifica 115 pessoas que ocuparam cargos. A distribuição entre os grupos étnicos ocorreu na forma apresentada no quadro abaixo:

Quadro 6 - Origens dos ocupantes de cargos na Irmandade de N.S. do Rosário de Mariana (1747-1810)

\begin{tabular}{|l|c|c|}
\hline ORIGENS & No & $\%$ \\
\hline África Ocidental & 56 & 48,7 \\
Mina & 14 & 12,2 \\
Courana & 03 & 2,6 \\
Fom & 03 & 2,6 \\
Cabo Verde & 01 & 0,9 \\
Courá & 09 & 7,8 \\
\hline África Centro-Ocidental & 01 & 0,9 \\
Angola & & \\
Congo & 09 & 7,8 \\
\hline Nascidos na Colônia & & \\
Crioulo & 03 & 2,6 \\
\hline Não Identificadas & 16 & 13,9 \\
\hline Lada & 115 & 100,0 \\
\hline Não Mencionadas & \\
\hline TOTAIS &
\end{tabular}

Fonte: AEAM - Assento de Irmãos da Irmandade de N.S. do Rosário de Mariana (17471931).

Algumas considerações devem ser feitas quanto a estas composições. A diferenciação dos crioulos no interior do templo dava-se, efetivamente, em torno do culto de Santa Efigênia, o que reforça a hipótese da historicidade das devoções e o fato de que as recomposições étnicas em situações diversas também se valem de diferentes símbolos devocionais, explicitando-se tal fato na evidência de que, no Rio, Santa Efigênia estava identificada aos pretos minas. 
A importância desta diferenciação simbólica dos crioulos, em Mariana, torna-se significativa na medida em que, segundo o que os dados apontam, havia uma disputa entre os africanos no interior da Igreja do Rosário da cidade, principalmente, no interior das irmandades do Rosário e São Benedito. Nestas, fica claro que o poder e prestígio dos minas era muito forte. Outra questão curiosa é que os angolas, embora numericamente superiores aos couranos, ficaram em desvantagem na ocupação de cargos. Pode-se visualizar, principalmente, através da Irmandade do Rosário, que os grupos da África Ocidental exerceram um verdadeiro controle sobre a administração da irmandade, o que torna muito provável a hipótese de uma aliança entre estes grupos étnicos. Com isto a questão das clivagens étnicas não estaria, a meu ver, tão somente colocada entre africanos e crioulos. Mas antes de uma conclusão mais incisiva, tomarei como outro ponto de comparação a estruturação do culto em Vila Rica.

No caso de Vila Rica, como, formalmente, só existiam duas Irmandades do Rosário, a maneira de se diferenciar os devotos de cada um dos santos existentes nas igrejas é através da identificação dos juizados de santos que eles ocuparam. Os livros de assentos registram, em alguns casos, os irmãos que exerceram aquelas funções. Os juizados dos santos indicam uma escolha devocional clara dos irmãos que se filiaram aos dois Rosários de Vila Rica. Metodologicamente, trabalharei somente com aqueles que ocuparam um cargo, já que constituíam a maioria dos casos em ambas as irmandades. Na Irmandade do Rosário do Pilar $^{85}$, as menções aos juizados de santos concentraram-se na segunda metade do Setecentos, principalmente, em função da popularização dos chamados juizados por devoção. A eleição dos juízes para os santos denotava um grau de desenvolvimento da devoção, pois estes eram os responsáveis pelo engrandecimento do culto. Estes juízes eram eleitos anualmente e, geralmente, escolhidos entre as pessoas que tinham alguma posse dentro do grupo. Além de contribuírem com esmolas, tinham a incumbência de organizar a festa do orago ${ }^{86}$. Segundo Marcos Aguiar, fundamentalmente nas irmandades negras, as esmolas dos juízes eram a grande fonte de suas rendas. Na segunda metade do século XVIII, em função da diminuição das rendas, as irmandades generalizaram o cargo de juiz por devoção como forma de garantir o aumento das receitas com base no crescimento das esmolas. Esta categoria de juiz associou-se diretamente ao vigor que o culto dos respectivos santos tomava, atraindo mais juízes ${ }^{87}$. Os juizados, portanto, representavam uma 
escolha devocional clara dos irmãos que procuravam o prestígio do cargo agregado à proteção dos santos de sua predileção ${ }^{88}$. Observe-se como os grupos étnicos do Rosário do Pilar se distribuíam nos juizados dentro da irmandade.

Quadro 7 - Origens dos Juízes de Santa Efigênia no Rosário do Pilar de Vila Rica (1777-1810)

\begin{tabular}{|l|c|c|}
\hline ORIGENS & No & $\%$ \\
\hline África Ocidental & & \\
Mina & 09 & 9,0 \\
Coura & 01 & 1,0 \\
\hline África Centro-Ocidental & & \\
Angola & 16 & 16,0 \\
Congo & 01 & 1,0 \\
Benguela & 01 & 1,0 \\
Ganguela & 01 & 1,0 \\
Cabundá & 01 & 1,0 \\
\hline Nascidos na Colônia & & \\
Crioulo & 70 & 70,0 \\
\hline TOTAIS & 100 & 100,0 \\
\hline
\end{tabular}

* Dos 449 irmãos que ocuparam o Juizado de Santa Efigênia, 100 tiveram suas origens identificadas.

Fonte: CC - AEPNP - Livro $2^{\circ}$ - Termo dos Irmãos da Confraria de Nossa Senhora do Rosário de Ouro Preto (1724-1873).

Quadro 8 - Origens dos Juízes de Santo Elesbão no Rosário do Pilar de Vila Rica (1779-1810)

\begin{tabular}{|l|c|c|}
\hline ORIGENS & No & $\%$ \\
\hline África Ocidental & & \\
Mina & 01 & 8,3 \\
\hline África Centro-Ocidental & & \\
Angola & 07 & 58,4 \\
Benguela & 01 & 8,3 \\
\hline Nascidos na Colônia & & \\
Crioulo & 03 & 25,0 \\
\hline TOTAIS & 12 & 100,0 \\
\hline
\end{tabular}

* Dos 71 irmãos que ocuparam o Juizado de Santo Elesbão, 12 tiveram suas origens identificadas. Fonte: CC - AEPNP - Livro $2^{\circ}$ - Termo dos Irmãos da Confraria de Nossa Senhora do Rosário de Ouro Preto (1724-1873). 
Quadro 9 - Origens dos Juízes de Nossa Senhora no Rosário do Pilar de Vila Rica (1776-1810)

\begin{tabular}{|l|c|c|}
\hline ORIGENS & No & $\%$ \\
\hline África Ocidental & & \\
Mina & 07 & 30,4 \\
Courá & 01 & 4,4 \\
\hline África Centro-Ocidental & & \\
Angola & 05 & 21,7 \\
Benguela & 01 & 4,4 \\
\hline Nascidos no Brasil & & \\
Crioulo & 09 & 39,1 \\
\hline TOTAIS & 23 & 100,0 \\
\hline
\end{tabular}

* Dos 78 irmãos que ocuparam o Juizado de Nossa Senhora, 23 tiveram suas origens identificadas.

Fonte: CC - AEPNP - Livro $2^{\circ}$ - Termo dos Irmãos da Confraria de Nossa Senhora do Rosário de Ouro Preto (1724-1873).

Quadro 10 - Origens dos Juízes de São Benedito no Rosário do Pilar de Vila Rica (1737-1810)

\begin{tabular}{|l|c|c|}
\hline ORIGENS & No & $\%$ \\
\hline $\begin{array}{l}\text { África Ocidental } \\
\text { Mina }\end{array}$ & 02 & 18,1 \\
\hline $\begin{array}{l}\text { África Centro-Ocidental } \\
\text { Angola }\end{array}$ & 04 & 36,4 \\
\hline $\begin{array}{l}\text { Nascidos na Colônia } \\
\text { Crioulos }\end{array}$ & 05 & 45,5 \\
\hline TOTAIS & 11 & 100,0 \\
\hline
\end{tabular}

* Dos 53 irmãos que ocuparam o Juizado de São Benedito, 11 tiveram suas origens identificadas.

Fonte: CC - AEPNP - Livro $2^{\circ}$ - Termo dos Irmãos da Confraria de Nossa Senhora do Rosário de Ouro Preto (1724-1873). 


\section{Quadro 11 - Origens dos Juízes de Santo Antônio de Categeró no Rosário do Pilar de Vila Rica (1735-1810)}

\begin{tabular}{|l|c|c|}
\hline ORIGENS & No & $\%$ \\
\hline $\begin{array}{l}\text { África Ocidental } \\
\text { Mina }\end{array}$ & 03 & 14,4 \\
\hline $\begin{array}{l}\text { África Centro-Ocidental } \\
\text { Angola }\end{array}$ & 09 & 42,8 \\
\hline $\begin{array}{l}\text { Nascidos na Colônia } \\
\text { Crioulo }\end{array}$ & 09 & 42,8 \\
\hline TOTAIS & 21 & 100,0 \\
\hline
\end{tabular}

* Dos 93 irmãos que ocuparam o Juizado de Santo Antônio de Categeró, 21 tiveram suas origens identificadas.

Fonte: CC - AEPNP - Livro $2^{\circ}$ - Termo dos Irmãos da Confraria de Nossa Senhora do Rosário de Ouro Preto (1724-1873).

Em Vila Rica observa-se, como em Mariana, uma concentração de crioulos entre os devotos de Efigênia. Este grupo, por sua vez, esteve bem representado em todas as devoçóes do templo. Tal fato pode ser explicado pelo aumento deste contingente populacional na segunda metade do século XVIII. Célia Borges já havia percebido esta "crioulização" das irmandades do Rosário no final do setecentos ${ }^{89}$. Em termos de curva demográfica, em diversas regiôes das Gerais, a população crioula começou a destacar-se na década de 1760 , atingindo contingentes consideráveis na década de $1780^{90}$. Isto, todavia, não anula o fato de que também, nesta irmandade, proporcionalmente, a escolha do grupo recaiu sobre o culto a Santa Efigênia, enquanto que, em relação a Santo Elesbão, os angolas assumiram um papel de maior relevância. É interessante perceber que, com relação aos arranjos dos grupos e das devoções, Santo Elesbão e Santa Efigênia estiveram dissociados em Minas, ao contrário do que foi observado para o Rio de Janeiro.

Comparando-se com a devoção a Nossa Senhora do Rosário é possível perceber que, embora não tanto como em Mariana, os minas, no âmbito desta associação, optaram muito mais por esse culto. Proporcionalmente, há uma concentração muito maior deste grupo como juízes de Nossa Senhora do que em qualquer outra devoção do templo. Tal fato ocorreu mesmo considerando-se a diminuição deste grupo dentro da irmandade, na segunda metade do século XVIII. Neste sentido, mais uma vez é possível 
afirmar que existiram composições internas na irmandade, visando à ocupação de cargos segundo critérios de disputas e de hierarquias, entre os grupos étnicos.

Para a análise desta situação no Rosário de Antônio Dias, trabalhei com dois livros de assentos de irmãos: o primeiro livro era destinado ao "assento dos irmãos brancos" e o segundo registrou somente a entrada de homens, não estabelecendo a cor dos mesmos no título do livro, no entanto, a maioria quase que absoluta dos assentados era de negros.

No livro destinado aos “irmãos brancos”, dos 355 registros entre 1729 e 1810, 20\% dos assentos eram de irmãos pardos. Oito escravos e 16 homens forros também foram registrados neste livro. Somente uma vez foi mencionada a origem de um irmão, era este um preto mina forro que foi juiz de São Benedito. Não houve caso de ocupação do juizado de Santo Elesbão entre os irmãos registrados neste livro. Entre os 106 irmãos que ocuparam o juizado de Santa Efigênia, foi possível identificar a cor de 55 deles: $81,8 \%$ eram pardos, $12,7 \%$ eram brancos, $3,6 \%$ eram cabras e $1,8 \%$ eram pretos. Dos seis que ocuparam o juizado de Nossa Senhora, o que teve a cor identificada era um branco. Entre os três juízes de Santo Antônio de Categeró, um pardo foi identificado ${ }^{91}$.

O segundo livro ${ }^{92}$, com 258 assentos, cobre o período de 1794 a 1810, e os juizados de santos estavam distribuídos da seguinte forma:

\section{Quadro 12 - Origens dos Juizes de Santa Efigênia no Rosário de Antonio Dias de Vila Rica (1794-1810)}

\begin{tabular}{|l|c|c|}
\hline ORIGENS & No & $\%$ \\
\hline África Ocidental & & \\
Mina & 07 & 13,5 \\
\hline África Centro-Ocidental & & \\
Angola & 17 & 32,7 \\
Congo & 01 & 1,9 \\
Rebolo & 01 & 1,9 \\
Cabinda & 01 & 1,9 \\
\hline Nascidos na Colônia & & \\
Crioulo & 25 & 48,1 \\
\hline TOTAIS & 52 & 100,0 \\
\hline
\end{tabular}

* Dos 78 irmãos que ocuparam o Juizado de Santa Efigênia, 52 tiveram suas origens identificadas.

Fonte: CC - AEPAD - Assento dos Irmãos da Irmandade de Nossa Senhora do Rosário da Paróquia de Antônio Dias (1794-1883). 
Quadro 13 - Origens dos Juízes de Santo Elesbão no Rosário de Antônio Dias de Vila Rica (1794-1810)

\begin{tabular}{|l|c|c|}
\hline ORIGENS & No & $\%$ \\
\hline $\begin{array}{l}\text { África Centro-Ocidental } \\
\text { Angola }\end{array}$ & 02 & 40,0 \\
\hline $\begin{array}{l}\text { Nascidos na Colônia } \\
\text { Crioulo }\end{array}$ & 03 & 60,0 \\
\hline TOTAIS & 05 & 100,0 \\
\hline
\end{tabular}

* Dos 8 irmãos que ocuparam o Juizado de Santo Elesbão, 5 tiveram suas origens identificadas.

Fonte: CC - AEPAD - Assento dos Irmãos da Irmandade de Nossa Senhora do Rosário da Paróquia de Antônio Dias (1794-1883).

Quadro 14 - Origens dos Juízes de Nossa Senhora no Rosário de Antônio Dias de Vila Rica (1794-1810)

\begin{tabular}{|l|c|c|}
\hline ORIGENS & No & $\%$ \\
\hline $\begin{array}{l}\text { África Centro-Ocidental } \\
\text { Angola }\end{array}$ & 02 & 50,0 \\
\hline $\begin{array}{l}\text { Nascidos no Brasil } \\
\text { Crioulo }\end{array}$ & 02 & 50,0 \\
\hline TOTAIS & 04 & 100,0 \\
\hline
\end{tabular}

*Dos 7 irmãos que ocuparam o Juizado de Nossa Senhora, 4 tiveram suas origens identificadas.

Fonte: CC - AEPAD - Assento dos Irmãos da Irmandade de Nossa Senhora do Rosário da Paróquia de Antônio Dias (1794-1883). 
Quadro 15 - Origens dos Juízes de São Benedito no Rosário de Antônio Dias de Vila Rica (1794-1810)

\begin{tabular}{|l|c|c|}
\hline ORIGENS & No & $\%$ \\
\hline África Ocidental & & \\
Mina & 01 & 14,3 \\
\hline África Centro-Ocidental & & \\
Angola & 01 & 14,3 \\
Congo & 01 & 14,3 \\
\hline Nascidos no Brasil & & \\
Crioulo & 04 & 57,1 \\
\hline TOTAIS & 07 & 100,0 \\
\hline
\end{tabular}

* Dos 13 irmãos que ocuparam o Juizado de São Benedito, 7 tiveram suas origens identificadas.

Fonte: CC - AEPAD - Assento dos Irmãos da Irmandade de Nossa Senhora do Rosário da Paróquia de Antônio Dias (1794-1883).

Quadro 16 - Origens dos Juízes de Santo Antônio de Categeró no Rosário de Antônio Dias de Vila Rica (1794-1810)

\begin{tabular}{|l|c|c|}
\hline ORIGENS & No & $\%$ \\
\hline África Ocidental & & \\
Mina & 01 & 10,0 \\
Nagô & 01 & 10,0 \\
\hline África Centro-Ocidental & & \\
Angola & 02 & 20,0 \\
Ganguela & 01 & 10,0 \\
\hline Nascidos na Colônia & 05 & 50,0 \\
Crioulo & 10 & 100,0 \\
\hline TOTAIS & & \\
\hline
\end{tabular}

* Dos 16 irmãos que ocuparam o Juizado de Santo Antônio de Categeró, 10 tiveram suas origens identificadas.

Fonte: CC - AEPAD - Assento dos Irmãos da Irmandade de Nossa Senhora do Rosário da Paróquia de Antônio Dias (1794-1883). 
Entre os juízes de Santa Efigênia novamente os crioulos se destacam, se bem que proporcionalmente estivessem mais representados nas outras devoções do templo. Todavia, não se pode esquecer que no livro dos "irmãos brancos" os pardos eram absoluta maioria entre os juízes desta santa. Não estou com isso querendo dizer que os pardos e os crioulos equivaliam-se quanto à condição social, tanto assim que os primeiros foram assentados no livro dos brancos. Como chama a atenção Hebe Castro, o designativo crioulo, em geral, era utilizado juntamente com preto para os escravos ou forros recentes. Ainda segundo a autora, o qualificativo pardo indicava, geralmente, os homens descendentes de africanos que conseguiam um certo reconhecimento de sua condição social de livres, ascendendo socialmente ${ }^{93}$.

No entanto, feita esta ressalva, é possível perceber um padrão devocional de escolha que aproximava crioulos e pardos no interior da irmandade. Em termos gerais, o pardo não deixava de ser um crioulo, considerando-se simplificadamente a questão da naturalidade. Os crioulos, por sua vez, como observou João Reis, estavam mais socializados no mundo dos brancos do que os africanos, o que não implica dizer que eram mais acomodados no interior do sistema escravista e nem que fosse impossível uma aliança entre crioulos e africanos ${ }^{94}$, porém, o que os dados demonstram é que, nesta irmandade, em particular, crioulos e pardos estavam muito mais próximos quando se tratava da devoção a Santa Efigênia.

José Carrato afirma, em relação a Minas, que Santa Efigênia seria a padroeira dos mulatos ${ }^{95}$. Esta designação, no entanto, é bastante complexa. Ora pode expressar ascendência social, ora a cor. Pode-se dizer que os mulatos, na Colônia, tratavam-se de mestiços, que também poderiam ser designados como pardos ${ }^{96}$. Neste sentido, os últimos dados com relação à devoção a Santa Efigênia podem corroborar, em parte, a afirmação de Carrato.

Em relação a Santo Elesbão, a preferência dos angolas por esta devoção continua a ser significativa, embora no Rosário do Pilar, proporcionalmente, esta fosse maior. Os angolas, diferentemente do observado para o Pilar, estavam mais concentrados na devoção a Nossa Senhora, ao passo que os minas que, no Pilar, concentravam-se mais nesta devoção, em Antônio Dias optaram preferencialmente por São Benedito e Santo Antônio de Categeró. 
Provavelmente, este mosaico de grupos e suas opções em torno das devoções inspirou os irmãos do Rosário do Pilar a redigirem seu compromisso, procurando evitar ou até mesmo solucionar problemas. O estatuto determinava que nos dias de festa se procedesse da seguinte forma: “... e não serão obrigados os Juízes nem Juízas de Nossa Senhora e mais Santos a ir buscá-los a sua casa e recebê-los a porta da Igreja para evitar distúrbios que poderão suceder, porém se, entre eles, houver boa união os poderão ir buscar a sua casa e acompanhá-los para a Igreja ..."97.

O fato de se colocar em compromisso o "evitar distúrbios" significava que, provavelmente, eles já teriam ocorrido. Se, como demonstrei, cada juizado representava a opção de um determinado grupo, os distúrbios teriam acontecido em função das disputas entre os mesmos, mais particularmente com o intuito de realizar a melhor festa para o seu respectivo orago. Neste sentido, e por tudo o que foi demonstrado, as clivagens étnicas existiam nas irmandades em Minas, não só entre os africanos e crioulos, mas também entre os próprios africanos, ao contrário do que argumenta Marcos Aguiar $^{98}$. Entretanto, um fator efetivamente diferenciava Minas Gerais e Rio de Janeiro. Em Minas, mesmo existindo a diferença entre os grupos, eles conseguiam estabelecer um grau de convivência dentro do mesmo templo. Como explicar esta questão?

No Rio, já na primeira metade do século XVIII, os grupos étnicos haviam começado a construir fronteiras entre as suas associações. Em 1700, a Irmandade de N.S. do Rosário e São Benedito iniciou a construção do seu templo que abrigou, preferencialmente, os "pretos Angola". Em 1740, a Irmandade de Santo Elesbão e Santa Efigênia constituiu-se como uma irmandade de "pretos" forros e escravos das naçóes Cabo Verde, Costa da Mina, Ilha de São Tomé e Moçambique, proibindo terminantemente a entrada de "pretos" de Angola, crioulos e mestiços. A Irmandade de N.S. da Lampadosa, constituída em 1747, por "pretos Minas", também não aceitava "pretos" de Angola. Cláudia Rodrigues, através dos registros de óbitos, demonstrou que os crioulos, no Rio, buscaram preferencialmente as igrejas paroquiais para os seus sepultamentos, afastando-se assim das igrejas de irmandades controladas por africanos, onde na maioria das vezes não eram bem vindos ${ }^{99}$. 
João Reis demonstrou para a Bahia um quadro semelhante, onde a explicitação verbal dos conflitos, através dos compromissos das irmandades, traduziu-se pela busca de espaços diferenciados pelos diversos grupos étnicos ${ }^{100}$. Como já observado, esta questão em Minas colocou-se de uma maneira um pouco diferente.

Comparando compromissos de irmandades negras de algumas regiões das Gerais, não encontrei o discurso exclusivista que caracterizou o Rio e a Bahia no mesmo período. O compromisso, de 1727, da Irmandade de São Benedito de Mariana falava na admissão de "todo homem ou mulher preto" que quisesse se assentar por irmão. O compromisso, de 1733, da Irmandade de N.S. do Rosário dos Pretos de Antônio Dias, em Vila Rica, afirmava que "entrará nesta Irmandade toda qualidade de pessoas sendo católicas" e "eles darão seus votos conformando-se com os Irmãos Pretos”. A Irmandade de Santo Elesbão e N.S. do Rosário da Freguesia de Pitangui, na Comarca do Rio das Velhas, no seu compromisso de 1767, admitia "irmãos pretos, pardos e brancos de um ou outro sexo". Em São José del Rei, Comarca do Rio das Mortes, a Irmandade de N.S. do Rosário dos Homens Pretos admitia por irmãos "todas as pessoas que, por sua devoção, quiserem servir a Nossa Senhora, tanto eclesiásticas, como seculares; homens e mulheres brancos, pardos e pretos, assim escravos como forros" ${ }^{\prime 101}$.

Célia Borges procura explicar esta especificidade reforçando a tese de Eduardo Hoornaert. Este autor afirma que a pressão e o maior controle da coroa portuguesa sobre a região mineradora influiu sobre a organização da religião em Minas, fazendo do excessivo fiscalismo um obstáculo para uma maior liberdade dos grupos organizados, entre eles as irmandades ${ }^{102}$.

Talvez esta análise explique parte da questão. Acredito que, numa perspectiva mais ampla, a especificidade de Minas deve ser buscada na própria formação daquela sociedade. Neste sentido, parto da hipótese de que o ocorrido em Minas, num primeiro momento, foi uma atitude de previdência tomada com relação aos recursos das irmandades negras.

Foram notórias as dificuldades que demarcaram o início do povoamento das Gerais. A instalação dos primeiros núcleos populacionais esbarrou na falta de alimentos, o que, por sua vez, acarretou a ocorrência de crises de fome e conseqüente dispersão populacional. Em Mariana, por 
exemplo, as crises mais graves ocorreram entre os anos de 1697-1698; 1701-1702. Como argumentam Carlos Guimarães e Liana Reis, foram estas crises que alertaram a coroa e a população sobre a necessidade de, juntamente com a mineração, se desenvolver empreendimentos agrícolas voltados para o abastecimento da região. Deste modo, segundo estes autores, a agricultura em Minas Gerais não se instalaria como uma resposta à crise da mineração, já que a atividade agrícola estava presente junto às áreas mineradoras na primeira metade do Setecentos ${ }^{103}$.

Analisando a questão para Mariana, Sônia Magalhães argumenta que a consolidação do núcleo urbano, a partir de 1711, só foi possível em larga escala, na medida em que as primeiras experiências com as crises de fome desenvolveram entre os marianenses um espírito preventivo que levou ao desbravar da região em torno do Ribeirão do Carmo, estabelecendo novos povoados e criando unidades agrícolas voltadas para o abastecimento interno. A ocorrência de crises de fome ainda se deu, em 1732, de forma mais branda, mas mesmo assim amedrontando a população. No século XIX, no ano de 1830, documentos da Câmara demonstravam ainda a preocupação com a alimentação da população e o temor de que retornassem as crises na mesma intensidade de outrora ${ }^{104}$.

É notória a constatação de que em meio a tais crises a população negra e pobre era a que mais sofria. A mortalidade entre esses segmentos foi altíssima durante todo o período colonial ${ }^{105}$. Seria de se esperar que, diante destas crises, este fosse o segmento da população que menos resistisse. Com relação aos forros, embora atualmente se questione o discurso que os via todos como homens pobres e miseráveis ${ }^{106}$, é importante reconhecer que a grande maioria dos setores negros da população era atingida pela marca da pobreza.

Outra questão a diferenciar o Rio de Janeiro de Minas estava no padrão de concentração das fortunas. Carla Almeida demonstrou que, em Minas, os percentuais das grandes fortunas sempre foram inferiores àqueles do Rio de Janeiro no mesmo período. Também o número de grandes fortunas no Rio sempre foi maior do que o encontrado em Minas Gerais ${ }^{107}$. Tais fatores levam a pensar que, no século XVIII, encontra-se em Minas uma sociedade em formação, ao passo que no Rio de Janeiro e mesmo na Bahia encontram-se sociedades mais consolidadas. 
Neste sentido, volto a insistir na atitude de previdência por parte das irmandades negras em Minas, pois diante desta conjuntura de formação social, penso que os irmãos negros optaram por não dispersar recursos materiais numa profusão de igrejas e irmandades. Jean Delumeau, analisando o temor da morte por fome na Europa, concluiu que, mesmo quando a fome era superada, as suas lembranças ficavam retidas no imaginário coletivo e não eram apagadas facilmente ${ }^{108}$. Creio que a ocorrência destas crises em Minas tenha deixado lembranças bem vivas, não se desejando revivê-las. Como as irmandades tinham funçôes devocionais e assistenciais bem definidas, teriam optado por concentrar aqueles recursos para possíveis eventualidades.

Com efeito, em Minas, o que me parece ter ocorrido com as irmandades negras foi a opção por uma união de recursos. Situações como estas, a exemplo do que sugere João Reis, podem ser propícias à criação de uma identidade marcada pela posição que a sociedade escravista reservava aqueles segmentos, entretanto, esta identidade não apagou as questões étnicas existentes entre os grupos ${ }^{109}$. Nesse sentido, acredito que a afirmação da diversidade foi a forma encontrada para a convivência, por mais que isso possa parecer contraditório. Os grupos presentes nas igrejas analisadas buscaram, a partir de então, hierarquizar espaços e definir poderes que permitissem a convivência.

Considerando-se as irmandades como uma das possibilidades de reconstrução de laços simbólicos parentais, através das identidades étnicas, é possível observar que o caso de Minas Gerais recoloca uma prática costumeira da África Centro-Ocidental, que era o estabelecimento de alianças para além das linhagens de origem. Segundo Joseph Miller, tal fato ocorria quando do interesse do grupo em atingir determinados objetivos, como a troca de conhecimentos relacionados à cura e à magia, ou mesmo conhecimentos relacionados à caça ${ }^{110}$. O que parece estar em jogo em Minas é a possibilidade de manutenção dos grupos, o que implicava necessariamente o estabelecimento de alianças e a convivência para além das fronteiras étnicas existentes.

Esta convivência, por sua vez, implicava o respeito pela devoção do outro, mesmo que de forma diferenciada e hierarquizada, questão que pode ser confirmada ao se ler o testamento de Rosa Maria da Conceição, 
preta forra, natural da Costa da Mina, residente em Mariana, que se declarou irmã de Santa Efigênia, São Benedito e Nossa Senhora do Rosário. Pedindo sepultura na Igreja do Rosário, Rosa solicitou que suas três irmandades a acompanhassem ao túmulo, deixando também a elas os seguintes legados: dez oitavas para a Irmandade de Nossa Senhora do Rosário e cinco oitavas para cada uma das outras irmandades. Semelhante distinção entre as devoções fez a preta forra Quitéria Cardoso Leal, também de Mariana, natural da Costa da Mina, irmã das três irmandades referidas para as quais deixou igualmente dez oitavas de esmola para o Rosário e cinco para São Benedito e Santa Efigênia ${ }^{111}$. Ambas as devotas pertenciam ao grupo preponderante dentro da igreja dos pretos de Mariana, o qual dominava os cargos da Irmandade do Rosário. Todavia, tanto Rosa quanto Quitéria prestavam reverência aos demais santos do templo.

Ao analisarem a questão da ida à missa como parte do ritual da feitura do iaô, no Candomblé, os autores do livro A Galinha d'Angola retomam, com base em Georges Dumézil, a problemática da evocatio romana ${ }^{112}$. A evocatio estabelecia como costume fazerem-se honrarias aos deuses dos adversários como forma de apaziguá-los e procurar cooptar os povos conquistados. Penso que tal explicação possa ajudar a compreender analogicamente a convivência e a mútua reverência, entre as devoções, em situaçōes precisas, pois se afirmava a diferença quando se privilegiava uma devoção, no entanto, via-se o respeito às demais como parte de uma regra de convivência. O simbolismo devocional, deste modo, possibilitava um diálogo que permitia a negociação entre os grupos e a construção de uma particular unidade dos negros daquele templo.

Nestes momentos precisos, talvez seja possível pensar para as irmandades em Minas a existência de uma comunidade negra que, diante de uma conjuntura particular, conseguia manter identidades particulares, mas ao mesmo tempo construir um consenso diante das conseqüências advindas do regime escravista para aquele grupo. Como ressalta Sheila Faria, a existência ou não da comunidade negra deve ser pensada segundo os condicionamentos históricos de cada região, não podendo ser generalizada para todos os lugares e momentos da história da escravidão ${ }^{113}$.

Em algumas situações, como esta que estou identificando, o espaço das irmandades demonstrou-se frutífero para a construção desta identida- 
de maior entre os negros ${ }^{114}$. Neste caso, mais uma vez as condições particulares de Minas se colocam como definidoras destas particularidades. Se, na primeira metade do século XVIII, uma atitude de previdência forçou a união, na segunda metade do setecentos, a crise da mineração deve ter tornado os irmãos ainda mais cautelosos.

Em 1770, os irmãos de Nossa Senhora do Rosário e São Benedito de Mariana resolveram que, a partir de então, teriam um procurador comum. Em 1778, a mesma decisão foi tomada em relação ao sacristão. Em 1792, as duas irmandades anteriores mais a de Santa Efigênia passaram a ter um único sacristão. Em 1807, deixando mais nítida a necessidade de poupar recursos, foi decido que:

... para ser útil aliviados das despesas que se podem escusar como é a conservação de dois capelães, que só um pode satisfazer as obrigações que lhes impõem os compromissos: portanto a exemplo das Irmandades do Alto da Cruz, que só conservam um capelão, e da mesma sorte a do Ouro Preto, acordaram todos uniformemente se conservasse um só capelão que satisfizesse a todas as obrigaçôes das Irmandades... ${ }^{115}$

Lembre-se que os cargos de sacristão e capelão eram remunerados pelas irmandades, entretanto, o consenso só foi possível, a meu ver, porque em Minas e, precisamente, nesta igreja de Mariana já havia uma larga experiência de união que permeava a regiáo. Note-se que as irmandades marianenses foram buscar exemplos nas suas congêneres negras de Vila Rica, cidade vizinha.

Os devotos do Rio de Janeiro, neste ponto, pareciam ser mais exclusivistas. Um exemplo disso pode ser visto numa amostragem do índice de filiaçôes às irmandades. Num universo de 95 testamentos de forros para o Rio e 95 testamentos para Mariana, encontrou-se de forma coincidente para as duas cidades o número de 74 testadores que fizeram menção às irmandades às quais eram filiados. Deste universo, em Mariana, 58\% dos testadores eram filiados somente a uma irmandade; no Rio, esse percentual era de $71,6 \%$.

Outro dado interessante surge quando se observa, especificamente, os devotos de Santa Efigênia, em Mariana, e os devotos de Santo Elesbão e Santa Efigênia, no Rio de Janeiro. Nesta última cidade, dos 13 testa- 
mentos de devotos de Elesbão e Efigênia, seis também eram irmãos de outra irmandade, enquanto sete eram irmãos somente da irmandade referida. Em Mariana, de um total de 17 testadores que se disseram irmãos de Santa Efigênia, somente três eram filiados exclusivos da dita irmandade ${ }^{116}$.

\section{4 - Conclusão}

O processo de cristianização de africanos e seus descendentes foi realmente um dos tópicos mais interessantes na história da diáspora. Inserese dentro daquilo que Stuart Hall denominou de uma "estética diaspórica"117, já que produziu constantemente uma apropriação e resignificação dos símbolos católicos segundo os valores das diversas culturas da África. Esta resignificação, como adverte Hall, não é um processo de volta às origens, mas sim a configuração de algo novo ${ }^{118}$, algo que não estava previsto e que remonta à criatividade cultural dos africanos e seus descendentes no contexto do escravismo colonial.

Este processo de criatividade cultural, no campo das religiosidades, reafirma o papel da devoção enquanto um importante sinal diacrítico na construção de identidades, inclusive de identidades étnicas. Reafirma também a historicidade da devoção, a qual era apropriada pelos diversos grupos étnicos de acordo com os arranjos econômicos, políticos e culturais de cada região. Esta apropriação, por sua vez, entre os negros do Rio de Janeiro e de Minas Gerais, conduziu a utilizaçôes diversas dos símbolos devocionais, também de acordo com as características históricas de cada uma destas regiôes, demarcando, por vezes, mais incisivamente a fronteira étnica ou flexibilizando esta fronteira, sem abrir mão da afirmação da diferença. Neste sentido, podese mais uma vez observar o caráter complexo da catequese, pois notadamente comprova-se a difusão do culto de Santo Elesbão e de Santa Efigênia entre os negros, todavia, esta comprovação também demonstra que, além do projeto idealizado, a vivência do culto possibilitou a afirmação de uma relativa autonomia dos grupos negros diante da uniformização pretendida pela Igreja. 


\section{Notas}

${ }^{1}$ FLORENTINO, Manolo. Em costas negras. Uma história do tráfico de escravos entre a África e o Rio de Janeiro. São Paulo: Cia. das Letras, 1997, p. 37.

${ }^{2}$ VAINFAS, Ronaldo. "Deus contra Palmares - Representações senhoriais e idéias jesuíticas”. In: REIS, João José e GOMES, Flávio dos Santos. Liberdade por um fio. História dos quilombos no Brasil. São Paulo: Cia. das Letras, 1996, p. 70-71.

${ }^{3}$ VAINFAS, Ronaldo. Ideologia e escravidão. Os letrados e a sociedade escravista no Brasil colonial. Petrópolis: Vozes, 1986, p. 96-98; OLIVEIRA, Anderson José Machado de. Os santos pretos carmelitas: culto dos santos, catequese e devoção negra no Brasil colonial. Tese de Doutorado apresentada ao Programa de Pós-Graduação em História Social da UFF. Niterói, 2002, p. 48-54.

${ }^{4}$ OLIVEIRA, Anderson José M. de. Op. cit., p. 60.

${ }^{5}$ Idem, p. 145.

${ }^{6}$ Idem, p. 80-84.

${ }^{7}$ SANTANA, Frei José Pereira de. Os Dois Atlantes de Etiópia. Santo Elesbão, Imperador XLVII da Abissinia, Advogado dos perigos do mar \& Santa Efigênia, Princesa da Núbia, Advogada dos incêndios dos edifícios. Ambos Carmelitas. Lisboa: Oficina de Antonio Pedrozo Galram, 17351738.

${ }^{8}$ ISICHEI, Elisabeth. A History of Christianity in Africa. New Jersey: Africa World Press, 1995, p. 30-31.

${ }^{9}$ OLIVEIRA, Anderson José M. de. Op. cit., p. 170-174.

${ }^{10}$ Idem, p. 241-242.

${ }^{11}$ Idem, p. 243-244.

${ }^{12}$ FARIA, Sheila de Castro. A Colônia em Movimento. Rio de Janeiro: Nova Fronteira, 1988, p. 135-139.

${ }^{13}$ MATTOS, Hebe Maria. "A escravidão moderna nos quadros do Império português: o Antigo Regime em perspectiva atlântica”. In: FRAGOSO, João; BICALHO, Maria Fernanda e GOUVÊA, Maria de Fátima (orgs.). O Antigo Regime nos Trópicos. Rio de Janeiro: Civilização Brasileira, 2001, p. 143.

${ }^{14}$ OLIVEIRA, Anderson José M. de. Op. cit., p. 249-344.

${ }^{15}$ AZZI, Riolando. A cristandade colonial: mito e ideologia. Petrópolis: Vozes, 1987, p. 61-62.

${ }^{16}$ THORNTON, John. Africa and Africans in the Making of the Atlantic World, 14001700. Second Edition. Cambridge: Cambridge University Press, 1998, p. 235-254.

${ }^{17}$ SANTANA, Frei José Pereira de. Sermão dos Santos Pretos Carmelitas. Elesbão, Imperador da Abssinia, e Efigênia, Princesa da Núbia. Lisboa: Officina da Antonio Pedrozo Galram, 1735, p. 07-08.

${ }^{18}$ OLIVEIRA, Anderson José Machado de. op. cit., p. 186. 
${ }^{19} \mathrm{BN}$ - (Biblioteca Nacional) SOUZA, Francisco. Regra ou Estatutos por modo de um diálogo onde se dá notícia das caridades sufragaçôes das almas que usam os pretos minas com os seus nacionais no Estado do Brasil. Rio de Janeiro, 1786, fol. 21.

${ }^{20}$ SOARES, Mariza de Carvalho. "O Império de Santo Elesbão na cidade do Rio de Janeiro, no século XVIII”. Topoi. Revista de História. Rio de Janeiro: Programa de PósGraduação em História da UFRJ/7Letras, v. 4, 2002, p. 68.

${ }^{21}$ CORNEVIN, Robert. Histoire du Dahomey. Paris: Éditions Berger-Levrault, 1962, p. 224.

${ }^{22}$ Idem, p. 224.

${ }^{23}$ MOTT, Luiz. Cotidiano e vivência religiosa: entre a capela e o calundu. In: SOUZA, Laura de Mello e (org.). História da vida privada no Brasil: cotidiano e vida privada na América portuguesa. São Paulo: Cia. das Letras, vol. 1, 1997, p. 156, 160, 164, 186.

${ }^{24}$ BAZIN, Germain. A arquitetura religiosa barroca no Brasil. Rio de Janeiro: Record, 1983; TRINDADE, Cônego Raimundo. Arquidiocese de Mariana: subsídios para sua História. São Paulo, 1929.

${ }^{25}$ CAMPOS, Adalgisa Arantes. "Mecenato e estilo rococó na época barroca: a Capela do Rosário dos Pretos de Vila Rica”. Texto apresentado no XXI Simpósio Nacional de História da ANPUH, Niterói, mímeo, 2001.

${ }^{26}$ AGUIAR, Marcos Magalhães de. "Festas e rituais de inversão hierárquica nas irmandades negras de Minas colonial”. In: JANCSÓ, István e KANTOR, Iris (orgs.). Festa: cultura e sociabilidade na América Portuguesa. São Paulo: Hucitec/EDUSP/FAPESP/Imprensa Oficial, vol. 1, 2001, p. 361-365.

${ }^{27}$ DURKHEIM, Émile. As formas elementares da vida religiosa: o sistema totêmico na Austrália. São Paulo: Paulinas, 1989, p. 152-153; 167.

${ }^{28}$ MILLER, Joseph C. Poder Político e Parentesco. Os Antigos Estados Mbundu em Angola. Luanda: Arquivo Histórico Nacional, 1995, p. 59-60.

${ }^{29}$ JUHÉ-BEAULATON, Dominique. “Arbres et bois sacrés de l'ancienne Côte des Esclaves”. In: CHRÉTIEN, Jean-Pierre et TRIAUD, Jean-Louis (direction). Histoire d'Afrique. Les enjeux de mémoire. Paris: Karthala, 1999, p. 102-103.

${ }^{30}$ AISESEF (Arquivo da Venerável Irmandade de Santo Elesbão e Santa Efigênia - RJ) Compromisso da Venerável Irmandade de Santo Elesbão e Santa Efigênia do Rio de Janeiro, 1740, fols. 11-12.

${ }^{31}$ LODY, Raul. O povo do santo: religiāo, história e cultura dos orixás, voduns, inquices e caboclos. Rio de Janeiro: Pallas, 1995, p. 54-57.

32 BOSCHI, Caio C. "Os históricos compromissos mineiros: riqueza e potencialidade de uma espécie documental”. Acervo: Revista do Arquivo Nacional. Rio de Janeiro, vol. 1, nº 1, 1986, p. 65.

${ }^{33}$ AARJ (Arquivo Arquidiocesano -RJ) - Livro de Óbitos e Testamentos da Freguesia do Santíssimo Sacramento (Antiga Sé), no 3 (1797-1812), p. 52 - Testamento de Gracia José Manoel, 1796. 
${ }^{34}$ RODRIGUES, Claudia. Nas Fronteiras do além: o processo de secularização da morte no Rio de Janeiro (século XVIII e XIX). Tese de Doutorado apresentada ao Programa de PósGraduação em História Social da UFF. Niterói, 2002, , p. 118-120.

35 POHL, Johann Emanuel. Viagem ao interior do Brasil. Belo Horizonte/São Paulo: Itatiaia/EDUSP, 1976, p. 203.

${ }^{36}$ REIS, João José. A morte é uma festa: ritos fúnebres e revolta popular no Brasil do século XIX. São Paulo: Cia. das Letras, 1991, p. 59-68.

${ }^{37} \mathrm{CC}$ (Casa dos Contos de Ouro Preto) - AEPNSP (Arquivo Eclesiástico da Paróquia do Pilar de Ouro Preto) - Compromisso da Irmandade de Nossa Senhora do Rosário dos Pretos da Freguesia de N.S. do Pilar (1750-1773), fol. 15.

${ }^{38}$ AGUIAR, Marcos Magalhães de. Op. cit., p. 361.

39 BRANDÃO, Carlos Rodrigues. A Festa do Santo de Preto. Rio de Janeiro/Goiânia: FUNARTE/Universidade Federal de Goiás, 1985, p. 88-90.

${ }^{40}$ LODY, Raul. Op. cit., p. 104-105.

${ }^{41}$ PRIORE, Mary del. Festas no Brasil colonial. São Paulo: Brasiliense, 1994, p. 77-87.

42 SILVA, Antônio de Moraes. Dicionário da Língua Portuguesa. Lisboa: Tipografia Lacerdina, 1813.

${ }^{43}$ BLUTEAU, Raphael. Vocabulário Portuguez e Latino. Coimbra: Colégio das Artes da Companhia de Jesus, 1712.

${ }^{44}$ Esta designação é dada pelo próprio compromisso da irmandade.

${ }^{45}$ AISESEF - Compromisso da Venerável Irmandade de Santo Elesbão e Santa Efigênia do Rio de Janeiro, 1740, fols. 29-31.

${ }^{46}$ SOARES, Mariza de Carvalho. Devotos da cor: identidade étnica, religiosidade e escravidão no Rio de Janeiro, século XVIII. Rio de Janeiro: Civilização Brasileira, 2000, p. 190191.

${ }^{47}$ SILVA, Alberto da Costa e. A Manilha e o Libambo. A África e a escravidão de 1500 a 1700. Rio de Janeiro: Nova Fronteira/Biblioteca Nacional, 2002, p. 527.

${ }^{48}$ CORNEVIN, Robert. op. cit., p. 149.

${ }^{49} C f:$ LAW, Robin. “The Oyo-Dahomey Wars, 1726-1823: a military analysis”. In: FALOLA, Toyin. Warfare and Diplomacy in Precolonial Nigeria. Madison: University of WisconsinMadison, 1992, p. 09-10.

${ }^{50} C f$ : REIS, João José. Magia Jeje na Bahia: a invasão do calundu do Pasto de Cachoeira, 1785. Revista Brasileira de História. São Paulo, vol. 8, n. 16, 1988.

${ }^{51}$ AISESEF - Compromisso da Venerável Irmandade de Santo Elesbão e Santa Efigênia do Rio de Janeiro, 1740, fol. 31.

52 SANTANA, Frei José Pereira de. Os Dois Atlantes de Etiópia, 1735, p. 28-30.

${ }^{53}$ VAINFAS, Ronaldo e SOUZA, Marina de Mello e. "Catolização e poder no tempo do tráfico: o reino do Congo da conversão coroada ao movimento antonino, século XV- 
XVIII". Tempo: Revista do Departamento de História da UFF. Rio de Janeiro: Sette Letras, vol. 3, no 6, 1998, p. 108-109, 117.

${ }^{4}$ SOUZA, Marina de Mello e. Reis Negros no Brasil Escravista: história da festa de coroação de Rei Congo. Belo Horizonte: UFMG, 2002, p. 47, 207-208.

${ }^{55}$ Idem, p. 181-182.

${ }^{56}$ SOARES, Mariza de Carvalho. Devotos da cor... p. 203.

${ }^{57}$ AARJ - Livro de Óbitos e Testamentos da Freguesia da Sé, no 18 (1776-1784), p. 442

v Testamento de Inácio Gonçalves do Monte, 1783.

58 SOUZA, Marina de Mello e. Op. cit., p. 178.

${ }^{59} \mathrm{O}$ termo recordaçôes é compreendido na concepção que lhe confere Robert Slenes, ou seja, um elemento que possibilitou a reconstrução da memória africana no Brasil escravista. Cf: SLENES, Robert W. Na senzala, uma flor: esperanças e recordaçôes na formação da familia escrava - Brasil, Sudeste, século XIX. Rio de Janeiro: Nova Fronteira, 1999, p. 131134.

${ }^{60}$ VASCONCELOS, Diogo de. História Antiga das Minas Gerais. 4a. ed. Belo Horizonte: Itatiaia, 1999, p. 343-344.

${ }^{61}$ ANASTASIA, Carla Maria Junho. Vassalos Rebeldes. Belo Horizonte: C/Arte, 1998, p. 126.

${ }^{62}$ MARKUS, Robert. O fim do Cristianismo Antigo. São Paulo: Paulus, 1997, p. 34.

${ }^{63}$ CUNHA, Manuela Carneiro da. Antropologia do Brasil: mito, história e etnicidade. São Paulo: Brasiliense/EDUSP, 1986, p. 94-95.

${ }^{64}$ OLIVEIRA, Anderson José M. de. "Santos Negros e Negros Devotos. A Irmandade de Santo Elesbão e Santa Efigênia no Rio de Janeiro, século XIX”. Cativeiro \& Liberdade: Revista Interdisplinar de História. Rio de Janeiro/Niterói: UFRJ/UFF, ano II, vol. 4, 1997. REIS, João José. "Identidade e diversidade étnicas nas irmandades negras no tempo da escravidão". Tempo: Revista do Departamento de História da UFF. Rio de Janeiro: Relume Dumará, vol. 2, no 3, 1997. SOARES, Marriza de Carvalho. Devotos da cor...

${ }^{65}$ POUTIGNAT, Philippe e STREIFF-FENART, Jocelyne. Teorias da Etnicidade. São Paulo: UNESP, 1998, p. 61-64; CUNHA, Manuela Carneiro da. Op. cit., p. 94.

${ }^{66}$ KARASCH, Mary C. A vida dos escravos no Rio de Janeiro 1808-1850. São Paulo: Cia. das Letras, 2000, p .35-66.

${ }^{67}$ REIS, João José. Rebelião escrava no Brasil: a história do levante dos malês (1835). 2a. ed. São Paulo: Brasiliense, 1987; Identidade e diversidade étnicas ...

${ }^{68}$ SOARES, Marriza de Carvalho. Devotos da cor...p. 109-119.

${ }^{69}$ CUNHA, Manuela Carneiro da. Op. cit., p. 94.

${ }^{70}$ CUNHA, Manuela Carneiro da. Op. cit., p. 93; OLIVEIRA, Roberto Cardoso de. Identidade, etnia e estrutura social. São Paulo: Pioneira, 1976, p. 103.

${ }^{71}$ AISESEF - Compromisso da Venerável Irmandade de Santo Elesbão e Santa Efigênia do Rio de Janeiro, 1740, fols. 01-02, documento anexo. (Grifos meus) 
${ }^{72}$ Idem, fols. 16-17.

${ }^{73}$ REIS, João José. “Identidade e diversidade étnicas...”, p. 16.

${ }^{74}$ SLENES, Robert W. "Malungu, Ngoma vem! África encoberta e descoberta no Brasil". Cadernos do Museu da Escravatura. Luanda: Ministério da Cultura, 1995.

${ }^{75}$ MINTZ, Sidney W. e PRICE, Richard. The birth of African-American culture. Beacon Press: Boston, 1192, p. 43.

${ }^{76}$ BOXER, Charles R. A Idade de Ouro do Brasil: dores de crescimento de uma sociedade colonial. Rio de Janeiro: Nova Fronteira, 2000, p. 200.

${ }^{77}$ ARIÈS, Philippe. O homem diante da morte. 2a. ed. Rio de Janeiro: Francisco Alves, vol. 1, 1989, p. 34.

${ }^{78}$ A Freguesia da Sé, em 1826, passou a chamar-se Freguesia do Santíssimo Sacramento. Todavia, a partir de 1780, os livros do Arquivo Arquidiocesano do Rio de Janeiro passaram a identificá-la como Freguesia do Santíssimo Sacramento da Antiga Sé. A escolha desta freguesia justifica-se pelo fato de que as igrejas das irmandades negras estavam concentradas nesta circunscrição, inclusive a Igreja de Santo Elesbão e Santa Efigênia, embora a irmandade tenha sido originalmente fundada na Freguesia da Candelária.

${ }^{79}$ RODRIGUES, Claudia. Lugares dos mortos na cidade dos vivos: tradiçōes e transformaçôes fúnebres no Rio de Janeiro. Rio de Janeiro: Secretaria Municipal de Cultura do Rio de Janeiro, 1997, p. 231.

${ }^{80}$ OLIVEIRA, Anderson José M. de. “Santos Negros e Negros Devotos...”, p. 28-29.

${ }^{81}$ AGUIAR, Marcos Magalhães de. Vila Rica dos Confrades: a sociabilidade confrarial entre os negros e mulatos no século XVIII. Dissertação de Mestrado apresentada ao Programa de Pós-Graduação em História Social da USP. São Paulo, 1993, p. 300.

${ }^{82}$ AEAM (Arquivo Eclesiástico de Mariana) - Assento de Irmãos da Irmandade de São Benedito de Mariana (1727-1842); Assento de Irmãos da Irmandade de Sana Efigênia de Mariana (1737-1810); Assento de Irmãos da Irmandade de N. S. do Rosário de Mariana (1747-1931).

${ }^{83}$ LUNA, Francisco Vidal e COSTA, Iraci Del Nero da. Minas Colonial: economia e sociedade. São Paulo: FIPE/Pioneira, 1982, p. 48-49.

${ }^{84}$ SOARES, Mariza de Carvalho. Devotos da cor... p. 180-189.

85 Trabalhei para esta irmandade um total de 3203 registros de filiação. No que tange a condição dos irmãos, no período analisado, 2028 eram escravos, 382 eram forros, 4 eram coartados, ninguém foi mencionado como livre e 789 registros não informaram a condição do associado. Fonte: CC - AEPNP - Livro $2^{\circ}$ - Termo dos Irmãos da Confraria de Nossa Senhora do Rosário de Ouro Preto (1724-1873).

${ }^{86}$ OLIVEIRA, Anderson José M. de. Os Santos Pretos Carmelitas ...., p. 360-361.

${ }^{87}$ AGUIAR, Marcos Magalhães de. Vila Rica dos confrades..., p. 178-188.

${ }^{88}$ OLIVEIRA, Anderson José M. de. Os Santos Pretos Carmelitas ...., p. 390. 
${ }^{89}$ BORGES, Célia Aparecida Resende Maia. Devoção branca de homens negros: as irmandades do Rosário em Minas Gerais no século XVIII. Tese de Doutorado apresentada ao Programa de Pós-Graduação em História Social da UFF. Niterói, 1998, P. 147.

${ }^{90}$ BEGARD, Laird W. Slavery and the Demographic and Economic History of Minas Gerais, Brazil, 1720-1888. Cambridge: Cambridge University Press, 1999, P. 125.

${ }^{91}$ CC - AEPAD (Arquivo Eclesiástico da Paróquia de Antônio Dias de Ouro Preto) Livro para o assento dos irmãos brancos da Irmandade de Nossa Senhora do Rosário da Paróquia de Antônio Dias (1737-1829).

${ }^{92}$ Neste livro foram assentados 162 irmãos que eram escravos, 59 que eram forros, 2 cortados e 35 não tiveram a condição mencionada.

${ }^{93}$ CASTRO, Hebe Maria Mattos de. Das cores do silêncio: os significados da liberdade no sudeste escravista - Brasil século XIX. Rio de Janeiro: Arquivo Nacional, 1995, p. 34-35. ${ }^{94}$ REIS, João José. Rebeliāo escrava no Brasil ..., p. 173-175.

${ }^{95}$ CARRATO, José Ferreira. Igreja, Iluminismo e Escolas Mineiras Coloniais. São Paulo: Editora Nacional, 1968, p. 48.

${ }^{96}$ VAINFAS, Ronaldo. "Mulatos". In: Dicionário do Brasil Colonial (1500-1808). Rio de Janeiro: Objetiva, 2000, p. 413-414.

${ }^{97}$ CC - AEPNSP - Compromisso da Irmandade de Nossa Senhora do Rosário dos Pretos da Freguesia de N.S. do Pilar (1750-1773), fol. 07.

${ }^{98}$ AGUIAR, Marcos Magalhães de. Vila Rica dos confrades..., p. 300.

${ }^{99}$ OLIVEIRA, Anderson José M. de. "Santos Negros e Negros Devotos ...”, p. 21; ARAUJO, José de Souza Azevedo Pizarro e. Memórias Históricas do Rio de Janeiro. Rio de Janeiro: Imprensa Nacional, 1945, p 40-41; FRIDMAN, Fania. Donos do Rio em Nome do Rei: uma história fundiária da cidade do Rio de Janeiro. Rio de Janeiro: Zahar/Garamond, 1999, p. 34-35; RODRIGUES, Claudia. Op. cit., p. 234-235.

${ }^{100}$ REIS, João José. "Identidade e diversidade étnicas ..."

${ }^{101}$ AEAM - Compromisso da Irmandade de S. Benedito da Cidade de Mariana (Transcrição do manuscrito original depositado no Arquivo Nacional da Torre do Tombo), 1727, Capítulo 1; ANTT (Arquivo Nacional da Torre do Tombo)- Chancelaria da Ordem de Cristo, Livro 17, Compromisso da Irmandade de Nossa Senhora do Rosário dos Pretos da Freguesia de Nossa Senhora da Conceição de Antônio Dias de Vila Rica do Ouro Preto (1733-1785), Capítulo 22; Chancelaria da Antiga Ordem de Cristo, Livro 291. Compromisso da Irmandade de Santo Elesbão e Nossa Senhora do Rosário do Arraial do Onça, Freguesia de Pitangui, 1767, Capítulo 1, ANSP - SJDR (Arquivo da Paróquia de Nossa Senhora do Pilar de São João del Rei)- Compromisso da Irmandade de N.S. do Rosário dos Homens Pretos da Vila de São José, 1811, Capítulo 7.

${ }^{102}$ BORGES, Célia Aparecida Resende Maia. Op. cit., p. 162; HOORNAERT, Eduardo. Formação do catolicismo brasileiro 1500-1800. 3a. ed. Petrópolis: Vozes, 1991, p. 88-91. 
103 GUIMARÃES, Carlos Magno e REIS, Liana Maria. "Agricultura e escravidão em Minas Gerais (1700-1750)”. Revista do Departamento de História da UFMG. Belo Horizonte, vol. 1, no2, 1986, p. 26.

${ }^{104}$ MAGALHĀES, Sônia Maria de. A Mesa de Mariana: produção e consumo de alimentos em Minas Gerais (1750-1850). Dissertação de Mestrado ao Programa de Pós-Graduação em História da Universidade Estadual Paulista. Franca, 1998, p. 43-46.

${ }^{105}$ FARIA, Sheila de Castro A Colônia em Movimento..., p. 301.

${ }^{106}$ FARIA, Sheila de Castro. "Mulheres forras - riqueza e estigma social”. Tempo: Revista do Departamento de História da UFF. Rio de Janeiro: Sette Letras, vol. 5, no 9, 2000, p. 78-80.

${ }^{107}$ ALMEIDA, Carla Maria Carvalho de. Homens ricos, homens bons: produção e hierarquização social em Minas Colonial, 1750-1822. Tese de Doutorado apresentada ao Programa de Pós-Graduação em História Social da UFF. Niterói, 2001, p. 193-195.

${ }^{108}$ DELUMEAU, Jean. História do Medo no Ocidente 1300-1800. São Paulo: Cia. das Letras, 1990, p. 174.

${ }^{109}$ REIS, João José e SILVA, Eduardo. Negociação e conflito: a resistência negra no Brasil escravista. São Paulo: Cia. das Letras, 1989, p. 109.

${ }^{110}$ MILLER, Joseph C. Op. cit., p. 49-51.

${ }^{111}$ ACSM (Arquivo da Casa Setecentista de Mariana)- Testamento de Rosa Maria Carvalho, 1762, - Livro de Registro de Testamentos do $1^{\circ}$ Ofício, fol. 69; Testamento de Quitéria Cardoso Leal, 1767 - Livro de Registro de Testamentos do $1^{\circ}$ Ofício, fol. 185. ${ }^{112}$ VOGEL, Arno, MELLO, Marco Antonio da Silva, BARROS, José Flávio Pessoa de. A Galinha d'Angola: iniciação e identidade na cultura afro-brasileira. Rio de Janeiro/Niterói: Pallas/FLACSO/EDUFF, 1993, p. 149.

${ }^{113}$ FARIA, Sheila de Castro. Cotidiano dos negros no Brasil escravista. Niterói, (mímeo), 2001, p. 63.

${ }^{114}$ Herbert Klein elenca as irmandades entre as associações que viabilizaram a construção de uma comunidade negra. Cf: KLEIN, Herbert. La esclavitud africana en América Latina y el Caribe. Madrid: Alianza Editorial, 1986, p. 119.

${ }^{115}$ AEAM - Livro de Atas da Irmandade de Nossa Senhora do Rosário dos Pretos de Mariana (1747-1856), fol. 101v.

${ }^{116}$ AARJ - Livros de Óbitos e Testamentos das Freguesias da Sé e Santíssimo Sacramento (1701-1812); ACSM - Livro de Registro de Testamentos do 1º Ofício (1727-1810).

${ }^{117}$ HALL, Stuart. Da Diáspora: identidades e mediaçôes culturais. Belo Horioznte/Brasília: Ed. da UFMG/Representação da UNESCO, 2003, p. 34.

${ }^{118}$ Idem, p. 35. 


\section{Referências bibliográficas}

AGUIAR, Marcos Magalhães de. "Festas e rituais de inversão hierárquica nas irmandades negras de Minas colonial”. In: JANCSÓ, István e KANTOR, Iris (orgs.). Festa: cultura e sociabilidade na América Portuguesa. São Paulo: Hucitec/EDUSP/ FAPESP/Imprensa Oficial, vol. 1, 2001.

-Vila Rica dos Confrades: a sociabilidade confrarial entre os negros e mulatos no século XVIII. Dissertação de Mestrado apresentada ao Programa de Pós-Graduação em História Social da USP. São Paulo, 1993.

ALMEIDA, Carla Maria Carvalho de. Homens ricos, homens bons: produção e hierarquização social em Minas Colonial, 1750-1822. Tese de Doutorado apresentada ao Programa de Pós-Graduação em História Social da UFF. Niterói, 2001.

ANASTASIA, Carla Maria Junho. Vassalos Rebeldes. Belo Horizonte: C/Arte, 1998. ARIĖS, Philippe. O homem diante da morte. $2^{\text {a }}$. ed. Rio de Janeiro: Francisco Alves, vol. 1, 1989.

AZZI, Riolando. A cristandade colonial: mito e ideologia. Petrópolis: Vozes, 1987. BEGARD, Laird W. Slavery and the Demographic and Economic History of Minas Gerais, Brazil, 1720-1888. Cambridge: Cambridge University Press, 1999.

BORGES, Célia Aparecida Resende Maia. Devoção branca de homens negros: as irmandades do Rosário em Minas Gerais no século XVIII. Tese de Doutorado apresentada ao Programa de Pós-Graduação em História Social da UFF. Niterói, 1998.

BOSCHI, Caio C. "Os históricos compromissos mineiros: riqueza e potencialidade de uma espécie documental”. Acervo: Revista do Arquivo Nacional. Rio de Janeiro, vol. 1, no 1, 1986.

BOXER, Charles R. A Idade de Ouro do Brasil: dores de crescimento de uma sociedade colonial. Rio de Janeiro: Nova Fronteira, 2000.

BRANDÃO, Carlos Rodrigues. A Festa do Santo de Preto. Rio de Janeiro/Goiânia: FUNARTE/Universidade Federal de Goiás, 1985.

CAMPOS, Adalgisa Arantes. "Mecenato e estilo rococó na época barroca: a Capela do Rosário dos Pretos de Vila Rica". Texto apresentado no XXI Simpósio Nacional de História da ANPUH, Niterói, mímeo, 2001.

CARRATO, José Ferreira. Igreja, Iluminismo e Escolas Mineiras Coloniais. São Paulo: Editora Nacional, 1968.

CASTRO, Hebe Maria Mattos de. Das cores do silêncio: os significados da liberdade no sudeste escravista - Brasil século XIX. Rio de Janeiro: Arquivo Nacional, 1995. 
CORNEVIN, Robert. Histoire du Dahomey. Paris: Éditions Berger-Levrault, 1962. CUNHA, Manuela Carneiro da. Antropologia do Brasil: mito, história e etnicidade. São Paulo: Brasiliense/EDUSP, 1986.

DELUMEAU, Jean. História do Medo no Ocidente 1300-1800. São Paulo: Cia. das Letras, 1990.

DURKHEIM, Émile. As formas elementares da vida religiosa: o sistema totêmico na Austrália. São Paulo: Paulinas, 1989.

FARIA, Sheila de Castro. A Colônia em Movimento. Rio de Janeiro: Nova Fronteira, 1988.

. Cotidiano dos negros no Brasil escravista. Niterói, (mímeo), 2001.

. "Mulheres forras - riqueza e estigma social". Tempo: Revista do Departamento de História da UFF. Rio de Janeiro: Sette Letras, vol. 5, no 9, 2000.

FLORENTINO, Manolo. Em costas negras. Uma história do tráfico de escravos entre a África e o Rio de Janeiro. São Paulo: Cia. das Letras, 1997.

GUIMARÃES, Carlos Magno e REIS, Liana Maria. "Agricultura e escravidão em Minas Gerais (1700-1750)". Revista do Departamento de História da UFMG. Belo Horizonte, vol. 1, n², 1986.

HALL, Stuart. Da Diáspora: identidades e mediaçôes culturais. Belo Horioznte/ Brasília: Ed. da UFMG/Representação da UNESCO, 2003.

HOORNAERT, Eduardo. Formação do catolicismo brasileiro 1500-1800. $3^{\mathrm{a}}$. ed. Petrópolis: Vozes, 1991.

ISICHEI, Elisabeth. A History of Christianity in Africa. New Jersey: Africa World Press, 1995.

JUHÉ-BEAUlatON, Dominique. Arbres et bois sacrés de l'ancienne Côte des Esclaves. In: CHRÉTIEN, Jean-Pierre et TRIAUD, Jean-Louis (direction). Histoire d'Afrique. Les enjeux de mémoire. Paris: Karthala, 1999.

KARASCH, Mary C. A vida dos escravos no Rio de Janeiro 1808-1850. São Paulo: Cia. das Letras, 2000.

KLEIN, Herbert. La esclavitud africana en América Latina y el Caribe. Madrid: Alianza Editorial, 1986.

LAW, Robin. "The Oyo-Dahomey Wars, 1726-1823: a military analysis". In: FALOLA, Toyin. Warfare and Diplomacy in Precolonial Nigeria. Madison: University of Wisconsin-Madison, 1992.

LODY, Raul. O povo do santo: religiāo, história e cultura dos orixás, voduns, inquices e caboclos. Rio de Janeiro: Pallas, 1995. 
LUNA, Francisco Vidal e COSTA, Iraci Del Nero da. Minas Colonial: economia e sociedade. São Paulo: FIPE/Pioneira, 1982.

MAGALHÃES, Sônia Maria de. A Mesa de Mariana: produção e consumo de alimentos em Minas Gerais (1750-1850). Dissertação de Mestrado ao Programa de Pós-Graduação em História da Universidade Estadual Paulista. Franca, 1998.

MARKUS, Robert. O fim do Cristianismo Antigo. São Paulo: Paulus, 1997.

MATTOS, Hebe Maria. "A escravidão moderna nos quadros do Império português: o Antigo Regime em perspectiva atlântica". In: FRAGOSO, João; BICALHO, Maria Fernanda e GOUVÊA, Maria de Fátima (orgs.). O Antigo Regime nos Trópicos. Rio de Janeiro: Civilização Brasileira, 2001.

MILLER, Joseph C. Poder Político e Parentesco. Os Antigos Estados Mbundu em Angola. Luanda: Arquivo Histórico Nacional, 1995.

MINTZ, Sidney W. e PRICE, Richard. The birth of African-American culture. Boston: Beacon Press, 1992.

MOTT, Luiz. "Cotidiano e vivência religiosa: entre a capela e o calundu". In: SOUZA, Laura de Mello e (org.). História da vida privada no Brasil: cotidiano e vida privada na América portuguesa. São Paulo: Cia. das Letras, vol. 1, 1997.

OLIVEIRA, Anderson José M. de. "Santos Negros e Negros Devotos. A Irmandade de Santo Elesbão e Santa Efigênia no Rio de Janeiro, século XIX". Cativeiro \& Liberdade: Revista Interdisplinar de História. Rio de Janeiro/Niterói: UFRJ/ UFF, ano II, vol. 4, 1997.

. Os santos pretos carmelitas: culto dos santos, catequese e devoção negra no Brasil colonial. Tese de Doutorado apresentada ao Programa de PósGraduação em História Social da UFF.Niterói, 2002.

OLIVEIRA, Roberto Cardoso de. Identidade, etnia e estrutura social. São Paulo: Pioneira, 1976.

POUTIGNAT, Philippe e STREIFF-FENART, Jocelyne. Teorias da Etnicidade. São Paulo: UNESP, 1998.

PRIORE, Mary del. Festas no Brasil colonial. São Paulo: Brasiliense, 1994.

REIS, João José e SILVA, Eduardo. Negociação e conflito: a resistência negra no Brasil escravista. São Paulo: Cia. das Letras, 1989.

REIS, João José. A morte é uma festa: ritos fúnebres e revolta popular no Brasil do século XIX. São Paulo: Cia. das Letras, 1991.

. "Identidade e diversidade étnicas nas irmandades negras no tempo da escravidão". Tempo: Revista do Departamento de História da UFF. Rio de Janeiro: Relume Dumará, vol. 2, no 3, 1997. 
. Rebelião escrava no Brasil: a história do levante dos malês (1835). $2^{\mathrm{a}}$. ed. São Paulo: Brasiliense, 1987.

- 'Magia Jeje na Bahia: a invasão do calundu do Pasto de Cachoeira, 1785'. Revista Brasileira de História. São Paulo, vol. 8, n. 16, 1988.

RODRIGUES, Claudia. Lugares dos mortos na cidade dos vivos: tradiçôes e transformaçôes fúnebres no Rio de Janeiro. Rio de Janeiro: Secretaria Municipal de Cultura do Rio de Janeiro, 1997.

- Nas Fronteiras do além: o processo de secularização da morte no Rio de Janeiro (séculos XVIII e XIX). Tese de Doutorado apresentada ao Programa de Pós-Graduação em História Social da UFF. Niterói, 2002.

SILVA, Alberto da Costa e. A Manilha e o Libambo. A África e a escravidão de 1500 a 1700. Rio de Janeiro: Nova Fronteira/Biblioteca Nacional, 2002.

SLENES, Robert W. "Malungu, Ngoma vem! África encoberta e descoberta no Brasil”. Cadernos do Museu da Escravatura. Luanda: Ministério da Cultura, 1995.

. Na senzala, uma flor: esperanças e recordações na formação da família escrava-Brasil, Sudeste, século XIX. Rio de Janeiro: Nova Fronteira, 1999.

SOARES, Mariza de Carvalho. Devotos da cor: identidade étnica, religiosidade e escravidão no Rio de Janeiro, século XVIII. Rio de Janeiro: Civilização Brasileira, 2000.

SOUZA, Marina de Mello e. Reis Negros no Brasil Escravista: história da festa de coroação de Rei Congo. Belo Horizonte: UFMG, 2002.

THORNTON, John. Africa and Africans in the Making of the Atlantic World, 1400-1700. Second Edition.Cambridge: Cambridge University Press, 1998.

VAINFAS, Ronaldo e SOUZA, Marina de Mello e. "Catolização e poder no tempo do tráfico: o reino do Congo da conversão coroada ao movimento antonino, séculos XV-XVIII". Tempo: Revista do Departamento de História da $U F F$. Rio de Janeiro: Sette Letras, vol. 3, no 6, 1998.

VAINFAS, Ronaldo. "Deus contra Palmares - Representaçôes senhoriais e idéias jesuíticas”. In: REIS, João José e GOMES, Flávio dos Santos. Liberdade por um fio. História dos quilombos no Brasil. São Paulo: Cia. das Letras, 1996. . Ideologia e escravidão. Os letrados e a sociedade escravista no Brasil colonial. Petrópolis: Vozes, 1986.

. "Mulatos". In: Dicionário do Brasil Colonial (1500-1808). Rio de Janeiro: Objetiva, 2000.

VASCONCELOS, Diogo de. História Antiga das Minas Gerais. 4ª ed. Belo Horizonte: Itatiaia, 1999. 
VOGEL, Arno, MELLO, Marco Antonio da Silva, BARROS, José Flávio Pessoa de. A Galinha d'Angola: iniciação e identidade na cultura afro-brasileira. Rio de Janeiro/Niterói: Pallas/FLACSO/EDUFF, 1993.

\section{Resumo}

O artigo procura refletir sobre o papel do culto de Santo Elesbão e Santa Efigênia, no século XVIII, como um dos fatores de construção de identidades entre segmentos da população negra no Brasil colonial. Defendo a idéia de que o estímulo ao culto fazia parte de uma das estratégias da Igreja na conversão de africanos e seus descendentes, no entanto, a complexidade do processo caracterizado pela diáspora das culturas africanas na América deu a este projeto de conversão outras dimensões. Num processo de criatividade e resistência culturais, as populaçōes de origem africana reinterpretaram os códigos católicos, conferindo ao culto dimensões outras que, se por um lado demonstraram em parte a eficácia do projeto com a aceitação dos símbolos católicos, por outro atestaram a existência de uma relativa autonomia das populaçôes negras conquistada em meio às lutas cotidianas no interior do sistema escravista.

Palavras-chave: culto dos santos; irmandades; identidade; catolicismo; escravidão.

\section{Abstract}

The article seeks reflect about the cult of Saint They and Saint Efigênia, into the $18^{\text {th }}$ century, like a from the factors of building of identities among segments from black people into the Brazil colonial. I defend the idea what the excitement the cult did breaks from a from the strategies from Church on conversion of Africans and yours descendants. However, the complexity of the process by diaspora from the cultures Africans in America gave to conversion another dimensions. On a resistance culture process, the populations of origin African reinterpreted the catholics codes, confering the cult dimensions another that if, on the one hand they demonstrated partly the efficiency of the project with the acceptability from the catholics symbols, for another to testify the lifetime from a relative to autonomy from the populations black conqueror half the struggles daily within of the slavery system.

Key words: cult of the saints; brotherhoods; identity; Catholicism; slavery. 